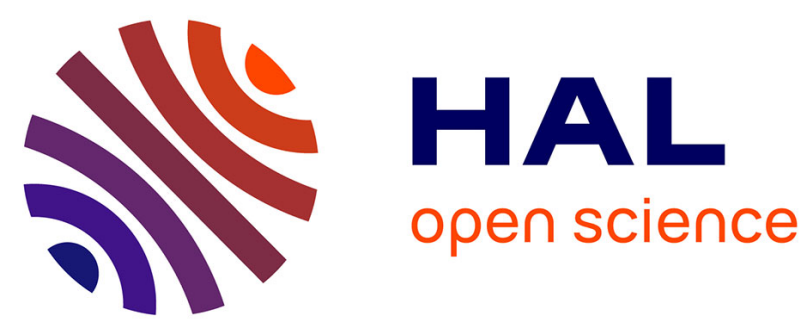

\title{
QUANTUM CHEMICAL STUDY OF THE THERMOCHEMICAL PROPERTIES OF ORGANOPHOSPHOROUS COMPOUNDS
}

A. Khalfa, M. Ferrari, R. Fournet, B. Sirjean, L. Verdier, Pierre-Alexandre Glaude

\section{To cite this version:}

A. Khalfa, M. Ferrari, R. Fournet, B. Sirjean, L. Verdier, et al.. QUANTUM CHEMICAL STUDY OF THE THERMOCHEMICAL PROPERTIES OF ORGANOPHOSPHOROUS COMPOUNDS. Journal of Physical Chemistry A, 2015, 119 (42), pp.10527-10539. 10.1021/acs.jpca.5b07071 . hal-01241498

\author{
HAL Id: hal-01241498 \\ https://hal.science/hal-01241498
}

Submitted on 10 Dec 2015

HAL is a multi-disciplinary open access archive for the deposit and dissemination of scientific research documents, whether they are published or not. The documents may come from teaching and research institutions in France or abroad, or from public or private research centers.
L'archive ouverte pluridisciplinaire HAL, est destinée au dépôt et à la diffusion de documents scientifiques de niveau recherche, publiés ou non, émanant des établissements d'enseignement et de recherche français ou étrangers, des laboratoires publics ou privés. 


\title{
QUANTUM CHEMICAL STUDY OF THE THERMOCHEMICAL PROPERTIES OF ORGANOPHOSPHOROUS COMPOUNDS
}

\author{
A. Khalfa, M. Ferrari ${ }^{1}$, R. Fournet ${ }^{1}$, B. Sirjean ${ }^{1}$, L. Verdier $^{2}$, P.A. Glaude ${ }^{1}$ \\ ${ }^{1}$ Laboratoire Réactions et Génie des Procédés, Université de Lorraine, CNRS, 1 rue Grandville, BP \\ 20451, 54001 NANCY Cedex, France,
}

${ }^{2}$ DGA Maîtrise NRBC, Site du Bouchet, 5 rue Lavoisier, BP n³, 91710 Vert le Petit, France

\begin{abstract}
Organophosphorous compounds are involved in many toxic compounds such as fungicides, pesticides, or chemical warfare nerve agents. The understanding of the decomposition chemistry of these compounds in the environment is largely limited by the scarcity of thermochemical data. Because of the high toxicity of many of these molecules, experimental determination of their thermochemical properties is very difficult. In this work, standard gas-phase thermodynamic data, i.e. enthalpies of formation $\left(\Delta \mathrm{H}_{\mathrm{f}}{ }^{\circ} 298\right)$, standard entropies $\left(\mathrm{S}^{\circ}{ }_{298}\right)$ and heat capacities $\left(\mathrm{C}_{\mathrm{p}}{ }^{\circ}(\mathrm{T})\right)$ were determined using quantum chemical calculations and more specifically the CBS-QB3 composite method which was found the best compromise between precision and calculation time among high accuracy composite methods. A large number of molecules was theoretically investigated, involving trivalent and pentavalent phosphorus atoms, and $\mathrm{C}, \mathrm{H}, \mathrm{O}, \mathrm{N}, \mathrm{S}$ and $\mathrm{F}$ atoms. These data were used to propose 83 original groups, used in the semi-empirical group contribution method proposed by Benson. Thanks to these latter group values, thermochemical properties of several nerve agents, common pesticides and herbicides have been evaluated. Bond dissociations energies (BDE), useful for the analysis the thermal stability of the compounds, were also determined in several molecules of interest.
\end{abstract}




\section{Introduction}

Organophosphorous compounds have been widely used as chemical warfare nerve agents ${ }^{1,2}$ and as pesticides ${ }^{3,4}$. In many countries, exposure to these latter chemicals remains a severe public health concern for children and people working in agriculture ${ }^{5}$. In addition to the dissemination of pesticides in the environment, toxic products can be released from unintentional combustion of such chemicals in case of accidental fire or burning of treated biomass ${ }^{6}$. These highly poisonous species belong to various organophosphorus families like phosphine oxides $\left(\mathrm{O}=\mathrm{PR}_{3}\right)$, phosphinates $\left(\mathrm{O}=\mathrm{P}(\mathrm{OR}) \mathrm{R}_{2}\right)$,

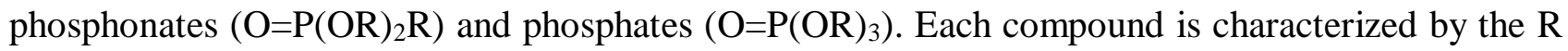
groups, which can be an alkyl chain, a sulfur group (e.g. in VX), an amine (e.g. in phenamiphos), a cyano group (e.g. in tabun) or a fluorine atom (e.g. in sarin and soman). The toxicity of these compounds is often lowered when shifting from a $\mathrm{P}=\mathrm{O}$ group to a $\mathrm{P}=\mathrm{S}$ central group; many insecticides involve thereby a thiophosphate (e.g. parathion or fenthion) or a thiophosphonate group (e.g. malathion). Figure 1 displays the structure of some organophosphorus compounds known as chemical agents, herbicides or pesticides. The understanding of the decomposition chemistry of these compounds as well as that of the subsequently formed radicals and/or molecules is largely limited by the scarcity of kinetic and thermochemical data ${ }^{7,8}$. Because of their high toxic nature, their experimental manipulation is very delicate and their thermochemistry is mostly unknown. Experimental thermochemical data are limited to light molecules ${ }^{9,10}$. Among heaver species,

measurements were performed for solid and triphenylphosphate ${ }^{11}$ and triphenyl phosphine sulfide ${ }^{12}$ and enthalpies of formation in the gas phase were calculated from the literature heat of vaporization. 
<smiles>CC(C)OP(C)(=O)F</smiles>

(a)<smiles>CCOP(=O)(C#N)N(C)C</smiles><smiles>COP(C)(=O)OC</smiles>

(e)

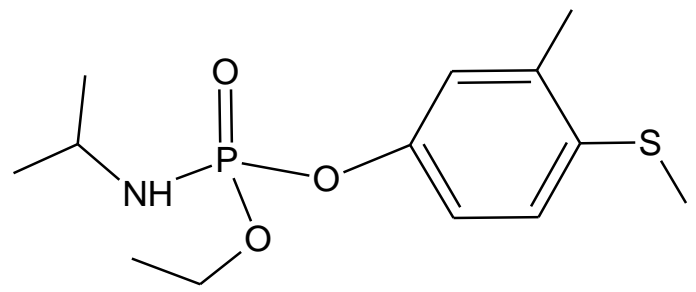<smiles>CC(OP(C)(=O)F)C(C)(C)C</smiles>

(b)<smiles>CCOP(C)(=O)SCCN(C(C)C)C(C)C</smiles>

(d)<smiles>O=C(O)CNCP(=O)(O)O</smiles>

(f)

(g)<smiles>COP(=S)(OC)Oc1c(Cl)cc(C)cc1Cl</smiles>

Figure 1. Examples of organophosphorus chemicals. Molecules of (a) Sarin, (b) Soman, (c) Tabun ,

(d) VX (chemical warfare nerve agents), (e) DMMP (surrogate and fire retardant), (f) Glyphosate (herbicide), (g) Fenamiphos (insecticide and nematicide), (h) Methyl Tolclofos (fungicide)

In the literature, quantum chemical calculations have been used to determine conformational and thermochemical properties of such systems containing trivalent or pentavalent phosphorus bonded to carbon, oxygen, nitrogen, sulfur, and fluorine atoms. One of the first attempts of a theoretical study of phosphorus oxides was led by Ewig and van Waser, who investigated the geometry of phosphinic, phosphonic and phosphoric acids ${ }^{13}$. More recently, the effect of substituents on geometry and stability of phosphonates ${ }^{14}$ and phenylphosphine ${ }^{15}$ has been studied by $a b$ initio and DFT methods, respectively. In the field of determination of thermochemical data, Leroy et al. ${ }^{16}$ calculated the enthalpy of formation of phosphorus compounds containing up to four heavy atoms. Calculations were performed at the MP2=FULL/6-31G(d,p) level of theory and enthalpies were derived from 
isodesmic reactions of hydrogenation. Bond dissociation energies of large diphosphines were calculated with ab initio (MP2) and DFT (B3LYP) methods by Borisenko and Rankin ${ }^{17}$, but the limited basis functions $(6-31+\mathrm{G}(\mathrm{d})$ and 3-21G(d), respectively) led to wide uncertainties. In order to improve the accuracy in the calculation of energy of large molecules, Melius and co-workers performed $a b$ initio calculations with bond additivity correction (BAC) procedures based on the MP4 $\operatorname{method}^{18}$ and on the G3 composite method ${ }^{19}$. They studied several light molecules such as methylphosphine $\mathrm{CH}_{3} \mathrm{PH}_{2}$, and the phosphorus oxides $\mathrm{HOP}=\mathrm{O}, \mathrm{HOPO}_{2}, \cdot \mathrm{P}(\mathrm{OH})_{2},(\mathrm{HO})_{2} \mathrm{P}=\mathrm{O}$, $(\mathrm{HO})_{3} \mathrm{P}$. At higher levels of theory, heats of formation of $\mathrm{PO}_{\mathrm{x}}$ and $\mathrm{PO}_{\mathrm{x}} \mathrm{H}(\mathrm{x}=1-3)$ were evaluated by Bauschlicher $^{20}$ using restricted coupled cluster single and double methods, based on B3LYP/6$31+\mathrm{G}(2 \mathrm{df})$ geometries. The accuracy of the calculations was increased by the extrapolation to the complete basis set (CBS) and the estimation of scalar relativistic effect. With the same methodology, Haworth et al. ${ }^{21,22}$ computed heats of formation of eighteen $\mathrm{PxHyOz}$ phosphorus compounds (up to $\mathrm{P}_{2} \mathrm{O}_{2}$ and $\mathrm{HOPO}_{2}$ ). Using these data obtained from high-level calculations and some literature measurements as a benchmark, they also showed that compounds G3, G3X and G3X2 methods led to reliable evaluations, within a $\pm 2 \mathrm{kcal} \mathrm{mol}^{-1}$ range of uncertainty. In 2000 , in the aim of investigating the thermal degradation of chemical warfare surrogates, Glaude et al. ${ }^{23}$ reported thermochemical data obtained with PM3 semi-empirical calculations ${ }^{24}$ for some heavier organophosphorus compounds like $\mathrm{P}=\mathrm{O}\left(\mathrm{CH}_{3}\right)\left(\mathrm{OCH}_{3}\right)_{2}$ (dimethyl methyl phosphonate, DMMP, a surrogate of nerve agents), $\mathrm{P}=\mathrm{O}(\mathrm{H})\left(\mathrm{CH}_{3}\right)\left(\mathrm{OCH}_{3}\right), \mathrm{P}=\mathrm{O}(\mathrm{OH})\left(\mathrm{CH}_{3}\right)\left(\mathrm{OCH}_{3}\right), \mathrm{P}=\mathrm{O}(\mathrm{OH})\left(\mathrm{OCH}_{3}\right)_{2}$, orthophosphoric acid $\mathrm{P}=\mathrm{O}(\mathrm{OH})_{3}$, $\mathrm{P}=\mathrm{O}(\mathrm{OH})_{2}\left(\mathrm{CH}_{3}\right)$. In 2004, Sullivan et al. ${ }^{8}$ calculated the thermochemical properties for 17 stable phosphorus-containing species using CBS-Q method ${ }^{25,26}$ and studied several organophosphorus free radicals such as $\mathrm{PO}(\mathrm{OH})_{2} \mathrm{CH}_{2} \bullet, \mathrm{PO}(\mathrm{O} \bullet) \mathrm{OHCH}_{3}$ and $\mathrm{PO}(\mathrm{OH})_{2} \mathrm{CH}_{2} \mathrm{O} \bullet$, with unknown thermochemical data. The team of Dorofeeva performed studies that are more comprehensive. The enthalpy of formation of 55 species involving trivalent phosphorus were calculated with the G3X composite $\operatorname{method}^{27}$. Thermochemical properties (enthalpy, entropy, and heat capacity) of 40 compounds containing pentavalent $\mathrm{P}$-atoms were evaluated at the same level of theory using the atomization energy procedure and an explicit treatment of the hindered rotors ${ }^{28}$. More recently, high accuracy theoretical calculation based on Coupled Cluster theory were implemented for the determination of enthalpy of formation of few phosphorus compounds, but only for species containing a limited number of heavy atoms ${ }^{29,30}$. Zhu and Bozzelli ${ }^{31,32}$ used several density functional and ab initio computational methods to determine thermochemical parameters, reaction paths, and kinetic barriers for sulfur 
compounds. They recommended the G3MP2 ${ }^{33}$ and $\mathrm{CBS}-\mathrm{QB} 3^{34}$ composite methods for these carbonsulfur-oxygen system, when they can be applied.

In this study, thermodynamic data were determined from $a b$ initio calculations for systems containing trivalent and pentavalent phosphorus atoms bonded to carbon, oxygen, nitrogen, sulphur, and fluorine atoms, corresponding to typical nerve agents and usual pesticides or herbicides. The aim is to determine enthalpies of formation $\left(\Delta_{f} H_{298}^{\circ}\right)$, standard entropies $\left(S_{298}^{\circ}\right)$ and heat capacities $\left(C_{p}^{\circ}(T)\right)$ with the accuracy necessary in the development of kinetic models. Different theoretical methods have been firstly envisaged to determine the best compromise between precision and calculation time. The large number and the large size of the molecules of interest does not allow a systematic evaluation of their thermodynamic data by means of high level theoretical calculations. The development of group contribution (GC) methods is an attractive alternative. GC models are predictive and widely used for the estimation of pure component-properties in gases or liquids ${ }^{35-37}$. Glaude et al. ${ }^{23}$ and Dorofeeva et al. ${ }^{27,38}$ have already proposed GCs determined thanks to theoretical calculations in the case of phosphorus containing systems. In a review on the calculation of thermodynamic properties of molecules, van Speybroeck et al..$^{39}$ considered that "currently, for larger molecules the combination of group contribution methods with group additive values that are determined with the best available computational ab initio methods seems to be a viable alternative to obtain thermodynamic properties with near chemical accuracy". The large number of species studied in the present work has allowed thereafter the determination of new groups used within the framework of Benson's GC theory ${ }^{35}$ for the evaluation of thermochemical properties of organophosphorus compounds. In addition, bond dissociation energies (BDE) have also been determined for some toxics that decompose under extreme temperature conditions. The determination of these unknown BDE values will allowing a preliminary analysis of the possible thermal decomposition pathways of the molecules. 


\section{Methodology}

\section{Computational Method}

The first step in this study focused on the choice of the calculation method for the optimization of the geometries, the calculation of the vibrational frequencies and the determination of the energies of the molecular structures. Given the nature $(\mathrm{P}, \mathrm{O}, \mathrm{C}, \mathrm{S}, \mathrm{N}, \mathrm{F})$ and the number of heavy atoms in the molecules (7 in DMMP, and 8 in Sarin for example), it was essential to use a level of theory able to achieve a good chemical accuracy within reasonable calculation times (a mean absolute deviation of $\pm 2 \mathrm{kcal} \mathrm{mol}^{-1}$ is aimed). Composite methods (CBS, G3, G3B3,...) are widely used because of their high precision even if they could be costly in time for large species. In this study, the CBS-QB3 ${ }^{34}$ level of theory has been used for the calculation of electronic energies. In order to check the accuracy of this method for the molecules of interest, calculations were performed for molecules and radicals with known enthalpies of formation, or which heat of formation could be calculated with other high accuracy methods. Gaussian $09^{40}$ software has been used to perform these calculations. For all the species considered, the enthalpies of formation $\left(\Delta_{f} H_{298}^{\circ}\right)$ were estimated using atomization reaction energies $^{41}$. The references for atomization energies of each atom were taken from CODATA database $^{42}$ and spin-orbit corrections were taken into account ${ }^{43}$. Values are displayed in the Supplemental Materiel. Atomization energies were preferred to isodesmic reactions because of the lack of reliable data to construct these latter. Usually, isodesmic reactions, hypothetical reactions that conserve the nature and the number of bonds in molecules between reactants and products, lead to more accurate values than the atomization reactions thanks to the cancellation of errors. However, the precision of the method lies on the availability and on the precision of the data for reference molecules used in the calculations. In the case of phosphorus compounds, the extreme paucity and the wide range of uncertainty of the enthalpies of formation in the literature make this approach untrustworthy, as already stated by Dorofeeva and Moiseeva ${ }^{27}$. Properties at $298 \mathrm{~K}$ were calculated thanks to ChemRate $^{44}$, which uses the outputs from Gaussian09.

For comparison, heats of formation have been calculated with the CBS-QB3, G4 and W1U composite methods known for their precision and compared to experimental data. The Gaussian-4 (G4) method $^{45}$, the last development of the GX series, is optimized for atoms of the first and second rows and allowed to lower the average absolute deviation from a set of experimental targets from 1.13 
$\mathrm{kcal} \mathrm{mol}^{-1}$ (G3 theory) to $0.83 \mathrm{kcal} \mathrm{mol}^{-1}$ (G4 theory). The Weizmann-1 theory ${ }^{46}$ and its unrestricted spin contamination corrected $\mathrm{W} 1 \mathrm{U}^{47}$ were developed to reduce the mean absolute errors in calculated heats of formation of molecules, which involved atoms from the first and second rows. A 0.44 kcal $\mathrm{mol}^{-1}$ mean absolute deviation was obtained against 220 total atomization energies, electron affinities, ionization potentials, and proton affinities of the G2/97 set ${ }^{47}$. The energy calculations are based on $\mathrm{CC}$ theory and contains corrections for scalar relativistic effects. An important quality of this method when employed as a benchmark for more approximate calculations is that it does not depend of empirical correction fitted from experimental data. Note that in these three composite methods, geometries are optimized with DFT theory, using the B3LYP functional and 6-311G(2d,d,p) (CBSQB3 theory), 6-31G(2df,p) (G4 theory), CC-pVTZ+1d (W1U theory) basis sets, respectively.

An overview of the results obtained is presented in Table1. In addition, theoretical calculations by Haworth and Bacskay ${ }^{21}$ and experimental data from the literature are reported. Results show that the composite methods seem to be reliable for heteroatoms such as P, S or halogens, for molecules and radicals, and lead to values within the range of uncertainty of data from the literature. By comparison with the seventeen available experimental values, the mean absolute deviations are 2.3, 2.8 and $1.9 \mathrm{kcal} \mathrm{mol}^{-1}$, using CBS-QB3, G4, and W1U theory, respectively. These values decrease even to 1.7, 2.4 and $1.4 \mathrm{kcal} \mathrm{mol}^{-1}$ if we discarded from the set of molecules HPO, which experimental heat of formation looks especially uncertain. As expected, W1U method is the most precise, but CBS-QB3 errors are not much larger, while G4 leads to the largest discrepancies. Considering the limited amount of experimental data and their wide uncertainties, W1U calculations can also be used as a benchmark to compare the performance of CBS-QB3 and G4 theories. For the set of 22 molecules calculated with W1U method in Table 1, the mean absolute deviations are 1.56 and $1.84 \mathrm{kcal} \mathrm{mol}^{-1}$ between W1U and CBS-QB3 and G4, respectively. Again, the CBS-QB3 method looks a little more reliable than G4, despite the lower basis set used for the optimization of the geometry and the less refined energy calculations. This is of particular interest for the calculation of the energy of larger molecular structures in this work. On the average, G4 requires at least four times more computing time than CBS-QB3, while the computing time needed by W1U calculations is orders of magnitude longer. For instance, in the case of calculations performed with an IBM/P1600 cluster by using height parallel processors, HOPO calculation spent $4 \mathrm{~min}, 33 \mathrm{~min}$, and $277 \mathrm{~min}$ of CPU time with respectively, CBSQB3, G4, and W1U methods. In the case of PF5, involving six heavy atoms, respective CPU time requirements were $17 \mathrm{~min}, 76 \mathrm{~min}$, and 121 hours. The robustness of the CBS-QB3 method has often 
be underlined in the literature. For molecules as heavy and constrained as $\mathrm{P}_{4} \mathrm{O}_{6}$ and $\mathrm{P}_{4} \mathrm{O}_{10}$, results were obtained in a good agreement with Gurvich et al. ${ }^{9}$ values, while G4 calculation did not converge with Gaussian09, just as W1U failed in the case of PS. The structure of heaviest calculated oxides, $\mathrm{P}_{4} \mathrm{O}_{6}$ and $\mathrm{P}_{4} \mathrm{O}_{10}$, is displayed in Figure 2. Bond lengths and angles are consistent with experimental data reported by Gurvich et al. ${ }^{9}$, which are given below the calculated values in Figure 2. Vibrational spectra are given in the Supplemental Material.

Table 1: Enthalpy of formation $\Delta_{f} H_{298}^{\circ}\left(\mathrm{kcal} \mathrm{mol}^{-1}\right)$ of several species from literature and from ab initio calculations

\begin{tabular}{|c|c|c|c|c|c|c|}
\hline Species & CBS-QB3 & G4 & W1U & $\begin{array}{c}\mathrm{CCSD}(\mathrm{T}) / \\
\mathrm{CBS}^{a}\end{array}$ & Experimental & \\
\hline $\mathrm{P}_{2}$ & 34.0 & 34.8 & 35.5 & 34.4 & $\begin{array}{r}34.4 \pm 0.5 \\
34.3\end{array}$ & \\
\hline $\mathrm{P}_{4}$ & 11.7 & 14.7 & 15.2 & 12.1 & $\begin{array}{r}14.1 \pm 0.1 \\
14.1\end{array}$ & $\begin{array}{l}b \\
c\end{array}$ \\
\hline $\mathrm{PO}$ & -8.2 & -9.3 & -6.4 & -7.6 & $\begin{array}{r}-6.5 \\
-6.7 \pm 0.8 \\
-5.60\end{array}$ & $\begin{array}{l}d \\
b \\
c\end{array}$ \\
\hline $\mathrm{PO}_{2}$ & -71.0 & -67.4 & -68.5 & -69.7 & $\begin{array}{r}-64.8 \\
-67.3 \pm 2.4 \\
-75.2\end{array}$ & $\begin{array}{l}d \\
b \\
c\end{array}$ \\
\hline $\mathrm{PO}_{3}$ & -108.1 & -104.4 & -105.7 & -107.7 & & \\
\hline $\mathrm{P}_{4} \mathrm{O}_{6}$ & -399.3 & $f$ & & & $\begin{array}{r}-383.8 \pm 9.6 \\
-529.2\end{array}$ & ${ }^{b}$ \\
\hline $\mathrm{P}_{4} \mathrm{O}_{10}$ & -695.5 & $f$ & & & $\begin{array}{r}-694.6 \pm 1.4 \\
-694.1\end{array}$ & ${ }_{c}^{b}$ \\
\hline PS & 35.2 & 38.8 & $f$ & & $\begin{array}{r}36.0 \pm 2.9 \\
33.1\end{array}$ & $\begin{array}{l}b \\
c\end{array}$ \\
\hline PN & 43.2 & 42.1 & 44.4 & & $\begin{array}{r}41.0 \pm 3.6 \\
25.1\end{array}$ & $\begin{array}{l}b \\
c\end{array}$ \\
\hline PH & 56.6 & 56.9 & 56.7 & 56.6 & $\begin{array}{l}55.2 \pm 3.1 \\
60.6 \pm 8.0\end{array}$ & $\begin{array}{l}b \\
c\end{array}$ \\
\hline $\mathrm{PH}_{2}$ & 31.2 & 32.8 & 31.9 & 31.5 & $\begin{array}{r}28.6 \pm 1.5 \\
30.1\end{array}$ & $\begin{array}{l}b \\
c\end{array}$ \\
\hline $\mathrm{PH}_{3}$ & 0.4 & 2.8 & 2.0 & 0.9 & 1.30 & $c$ \\
\hline HPO & -23.0 & -20.9 & -21.2 & -22.4 & $\begin{array}{r}-34.2 \\
-13.6 \pm 9.6\end{array}$ & $\begin{array}{l}e \\
b\end{array}$ \\
\hline $\mathrm{HPOH}$ & -23.6 & -21.9 & -23.4 & -24.4 & & \\
\hline $\mathrm{H}_{2} \mathrm{POH}$ & -49.8 & -47.1 & -49.2 & -50.2 & & \\
\hline $\mathrm{H}_{3} \mathrm{PO}$ & -51.7 & -47.2 & -50.1 & -51.5 & & \\
\hline
\end{tabular}




\begin{tabular}{|c|c|c|c|c|c|}
\hline HOPO & -110.8 & -108.7 & -110.2 & -112.0 & -110.6 \\
\hline HOPO2 & -168.7 & -165.3 & -168.0 & -170.6 & -168.8 \\
\hline PF & -12.9 & -13.1 & -13.6 & & $\begin{array}{r}-11.5 \pm 10.0 \\
-12.5\end{array}$ \\
\hline $\mathrm{PF}_{2}$ & -113.2 & -113.1 & -114.7 & & $\begin{array}{r}-122.6 \pm 9.6 \\
-116.7\end{array}$ \\
\hline $\mathrm{PF}_{3}$ & -226.2 & -226.0 & -228.8 & & $\begin{array}{r}-228.8 \pm 0.3 \\
-229.1\end{array}$ \\
\hline $\mathrm{PF}_{5}$ & -377.5 & -376.5 & -381.3 & & $\begin{array}{r}-380.8 \pm 0.3 \\
-381.1\end{array}$ \\
\hline $\mathrm{PCl}_{3}$ & -69.9 & -63.6 & -67.7 & & $\begin{array}{r}-69.2 \pm 0.5 \\
-69.0\end{array}$ \\
\hline $\mathrm{POCl}$ & -66.8 & -63.7 & -65.6 & & -60.2 \\
\hline $\mathrm{POF}_{3}$ & -300.4 & -298.9 & -302.1 & & $\begin{array}{r}-299.2 \pm 1.9 \\
-299.8\end{array}$ \\
\hline $\mathrm{POCl}_{3}$ & -134.9 & -128.4 & -132.6 & & $\begin{array}{r}-135.9 \pm 0.6 \\
-133.8\end{array}$ \\
\hline $\mathrm{PSF}_{3}$ & -237.8 & & & & -241.2 \\
\hline $\mathrm{PSCl}_{3}$ & -76.4 & & & & -91.0 \\
\hline$\cdot \mathrm{P}=\mathrm{O}(\mathrm{OH})_{2}$ & -157.9 & -154.5 & -156.8 & & \\
\hline
\end{tabular}

${ }^{a}$ From Haworth and Bacskay (2002) ${ }^{21}$. Geometries and vibrational frequencies calculated with the B3LYP/6-31G(2df,p) functional and basis set, energies calculated at CCSD(T)/CBS level including scalar relativistic corrections.

${ }^{b}$ From Gurvich et al. $(1989)^{9}$

${ }^{c}$ From JANAF tables ${ }^{10}$ accessed through the NIST Chemistry Webbook ${ }^{48}$. Note that the value for $\mathrm{P}_{4} \mathrm{O}_{6}$ looks erroneous, as reported by also in the Third Millennium Ideal Gas and Condensed Phase Thermochemical Database for Combustion ${ }^{49}$

${ }^{d}$ From Droward et al. $(1972)^{50}$

${ }^{e}$ From Hildenbrand and Lau $(1994)^{51}$

${ }^{f}$ Calculations with Gaussian09 did not converge in these cases. 

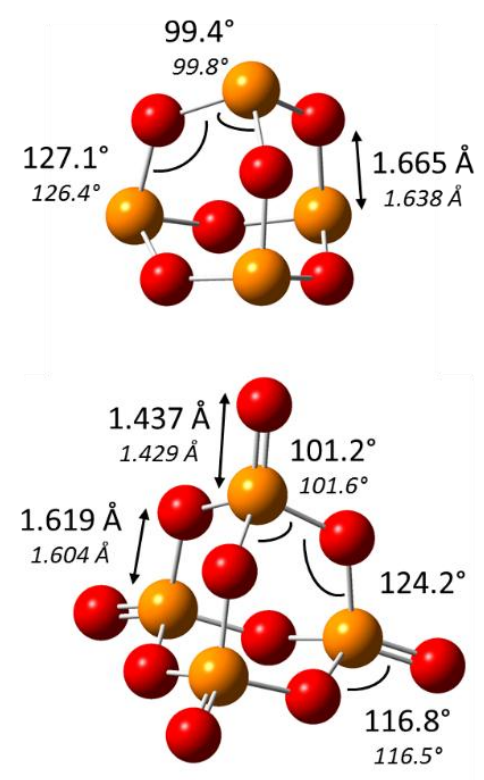

Figure 2. Structure of $\mathrm{P}_{4} \mathrm{O}_{6}$ and $\mathrm{P}_{4} \mathrm{O}_{10}$ optimized at the B3LYP/6-311G(2d,p,p) in the CBS-QB3 composite method. Calculated bond lengths and angles are displayed in normal case, italic numbers are experimental values reported by Gurvich et al. ${ }^{9}$

In the CBS-QB3 method, geometry and frequencies are calculated at the B3LYP ${ }^{52,53}$ level of theory with a 6-311G $(2 \mathrm{~d}, \mathrm{~d}, \mathrm{p})$ basis set (also designed as cbsb7). Entropies $\left(S_{298}^{\circ}\right)$, have been calculated taking into account hindered rotors contributions which have been evaluated to correct the partition functions. In this work, hindered internal rotations were treated using the following procedure. First, the potentials of each internal rotation were calculated at the B3LYP/6-31G(d,p) level of theory using a rigid energy scan. The characteristics of the rotational potentials and the corresponding barriers were used to correct the partition function using Pitzer and Gwinn tabulations ${ }^{54}$. Reduced moments of inertia for internal rotations were calculated for each species using B3LYP/6-311G(2d,d,p) geometries with the method of Pitzer implemented in ChemRate ${ }^{44,55}$. Using the CBS-QB3 method, the values of the frequencies must be weighed by a scaling factor equal to $0.99^{56}$. Table 2 compares calculated entropies to literature data for some phosphorus containing species, in which vibrational contribution play a role. The average absolute deviation is $0.68 \mathrm{cal} \mathrm{mol}^{-1} \mathrm{~K}^{-1}$. Note that no experimental data are available for phosphorus molecule involving an internal hindered rotor. 
Table 2: Entropy $S_{298}^{\circ}\left(\mathrm{cal} \mathrm{mol}^{-1} \mathrm{~K}^{-1}\right)$ of several species from literature and from ab initio calculations

\begin{tabular}{lrr}
\hline & This work & Literature $^{a}$ \\
\hline $\mathrm{P}_{4}$ & 67.12 & 66.89 \\
$\mathrm{P}_{4} \mathrm{O}_{6}$ & 84.73 & 85.18 \\
$\mathrm{P}_{4} \mathrm{O}_{10}$ & 96.90 & 96.10 \\
$\mathrm{PF}_{5}$ & 73.04 & 71.95 \\
$\mathrm{PCl}_{3}$ & 75.32 & 74.50 \\
$\mathrm{POF}_{3}$ & 68.94 & 68.22 \\
\hline
\end{tabular}

${ }^{a}$ From Gurvich et al. $(1989)^{9}$

\section{Group contribution method}

Benson $^{35}$ proposed a group contribution approach for the estimation of thermochemical data. The additivity principle states that a molecular property is composed of contributions due to groups. A group is defined as a polyvalent atom (valence number $\geq 2$ ), in a molecule together with all of its ligands. The same group is able to represent the molecular structure involved in different compounds. If this relatively simple but reliable method is widely used for hydrocarbons and $\mathrm{C} / \mathrm{H} / \mathrm{O} / \mathrm{N}$ compounds ${ }^{57-61}$, for which numerous experimental data were available, most groups remain unknown in the case of organophosphorous compounds. In this work, more than hundred and ninety molecules, which contain unknown groups present in pesticides and chemical warfare agents, were studied and their thermochemical properties were calculated systematically with the methodology described above. From these thermochemical data, several new groups were evaluated for trivalent and pentavalent phosphorus atoms bonded to carbon, oxygen, nitrogen, sulfur, or fluorine atoms, and for nitrogen and sulfur atoms. Each molecule studied was decomposed into groups, leading eventually to 58 known groups containing $\mathrm{C} / \mathrm{H} / \mathrm{O} / \mathrm{N} / \mathrm{S}$ atoms and 80 unknown new groups. Four groups for which data were already available were re-valuated. The known groups used as a basis for the evaluation of the new one are presented in Table 3. Their values are that proposed by Domalski and Hearing ${ }^{62}$, who performed an extended re-examination of the group values, using more than 3700 comparisons for 1500 organic compounds. Since these authors made recommendation for heat capacities only at room temperature, values of $C_{p}^{\circ}$ at higher temperature were taken from the original tables by Benson ${ }^{35}$. All 
of these data were already used in the software THERGAS ${ }^{60}$, which automatically calculates thermochemical properties of covalent molecules based on Benson's theory. Note that few groups such as $\mathrm{O}-(\mathrm{H})\left(\mathrm{C}_{\mathrm{d}}\right)$, which were not available in the original Benson groups nor in the work by Domalski and Hearing have been determined in the past by our research group from data for properties of single molecules published in the literature ${ }^{48}$.

The enthalpies of formation $\left(\Delta_{f} H_{298}^{\circ}\right)$, standard entropies $\left(S_{298}^{\circ}\right)$ and heat capacities $\left(C_{p}^{\circ}(T)\right)$ of other eighty unknown groups were optimized with at least three molecules per group. Note that all groups which consist in a methyl group bounded to a heteroatom were assumed to have the same contribution as the group $\mathrm{C}-(\mathrm{H})_{3}(\mathrm{C})$ since these values represent a degree of freedom in the optimization of the data. Some corrections of various types are also necessary in the method to estimate standard entropies. Optical isomer and symmetry corrections must be taken into account. Indeed, in a mixture of $n$ optical isomers, a term $R \ln (n)$ must be added to standard entropy, where $n$ is the number of optical isomers for a given species. Moreover, the symmetry number $\sigma$ is defined as the total of independent permutation of identical atoms (or groups) in a molecule, which can be obtained by rotation of the whole molecule, treated as a rigid body. The number thus defined corresponds to the external symmetry number $\sigma_{\text {ext }}$. For example, the $\mathrm{H}_{2} \mathrm{O}$ molecule has one second order axis and $\sigma_{\text {ext }}=2$; methane has four third order axis and $\sigma_{\text {ext }}=3 \times 4=12$. In some molecules, internal rotations of groups with respect to the rest of the molecule can exist. We then define an internal symmetry number $\sigma_{i n t}$. For example, propane has two internal rotations of $\mathrm{CH}_{3}$ groups around the $\sigma$ bonds and $\sigma_{i n t}=3^{2}=9$. The symmetry correction to the entropy for the total symmetry number $\sigma=\sigma_{\text {ext }} \cdot \sigma_{\text {int }}$ is equal to $-R \ln (\sigma)$. The entropy calculated from the additivity of groups is the intrinsic entropy $S_{i n t}^{\circ}$. The real entropy $S_{\text {real }}^{\circ}$, including corrections due to symmetry and optical isomers, is therefore :

$$
S_{\text {real }}^{\circ}=S_{\text {int }}^{\circ}-R \ln (\sigma)+R \ln (n)
$$

Bond dissociation energies (BDE) are critical data for the development of detailed chemical kinetic mechanisms. They allow the estimation of the most favored reaction pathways. For example, bond breakings with low BDE will be predominant in the unimolecular initiation reactions. The BDE estimation corresponds to the enthalpy of reaction $\Delta_{\mathrm{r}} \mathrm{H}_{298}^{\circ}$ for the dissociation of a molecule $\mathrm{RR}^{\prime}$ according to the reaction: $\mathrm{R}-\mathrm{R}^{\prime} \rightarrow \mathrm{R} \bullet+\mathrm{R}^{\prime} \bullet$ 


$$
B D E=\Delta_{r} H_{298}^{\circ} .=\Delta_{f} H_{298}^{\circ}(R \cdot)+\Delta_{f} H_{298}^{\circ}\left(R^{\prime} \cdot\right)-\Delta_{f} H_{298}^{\circ}\left(R R^{\prime}\right)
$$

Table 3: Group values already determined and used for the calculation of the new groups.

\begin{tabular}{|c|c|c|c|c|c|c|c|c|}
\hline \multirow[t]{2}{*}{ Groups $^{a}$} & \multirow{2}{*}{$\begin{array}{c}\Delta_{f} H_{298}^{\circ} \\
\left(\mathrm{kcal} \mathrm{mol}^{-1}\right)\end{array}$} & \multirow{2}{*}{$\begin{array}{c}S_{298}^{\circ} \\
\left(\mathrm{cal} \mathrm{mol}^{-1} \mathrm{~K}^{-1}\right)\end{array}$} & \multicolumn{6}{|c|}{$C_{p}^{\circ}(T)\left(\mathrm{cal} \mathrm{mol}^{-1} \mathrm{~K}^{-1}\right)$} \\
\hline & & & 300 & 400 & 500 & 600 & 800 & 1000 \\
\hline \multicolumn{9}{|c|}{$\mathrm{CH}$ groups } \\
\hline $\mathrm{C}-(\mathrm{H})_{3}(\mathrm{C})$ & -10.10 & 30.42 & 6.15 & 7.84 & 9.40 & 10.79 & 13.02 & 14.77 \\
\hline $\mathrm{C}-(\mathrm{H})_{2}(\mathrm{C})_{2}$ & -4.93 & 9.36 & 5.47 & 6.95 & 8.25 & 9.35 & 11.07 & 12.34 \\
\hline $\mathrm{C}-(\mathrm{H})(\mathrm{C})_{3}$ & -0.28 & -12.81 & 4.80 & 6.00 & 7.17 & 8.05 & 9.31 & 10.05 \\
\hline $\mathrm{C}-(\mathrm{C})_{4}$ & 4.59 & -35.72 & 3.95 & 6.13 & 7.36 & 8.12 & 8.77 & 8.76 \\
\hline $\mathrm{C}_{\mathrm{d}}-(\mathrm{H})_{2}$ & 6.29 & 27.60 & 5.11 & 6.36 & 7.51 & 8.50 & 10.07 & 11.27 \\
\hline $\mathrm{C}_{\mathrm{d}^{-}}(\mathrm{H})(\mathrm{C})$ & 8.68 & 7.90 & 4.48 & 5.03 & 5.81 & 6.50 & 7.65 & 8.45 \\
\hline $\mathrm{C}_{\mathrm{d}}-(\mathrm{C})_{2}$ & 10.55 & -12.15 & 3.61 & 4.61 & 4.99 & 5.26 & 5.80 & 6.08 \\
\hline $\mathrm{C}_{\mathrm{b}}-(\mathrm{H})$ & 3.30 & 11.54 & 3.25 & 4.44 & 5.46 & 6.30 & 7.54 & 8.41 \\
\hline $\mathrm{C}_{\mathrm{b}}-(\mathrm{C})$ & 5.65 & -8.51 & 2.33 & 2.81 & 3.35 & 3.82 & 4.63 & 5.11 \\
\hline \multicolumn{9}{|c|}{ CHO groups } \\
\hline $\mathrm{O}-(\mathrm{H})(\mathrm{C})$ & -38.07 & 29.03 & 4.34 & 4.45 & 4.82 & 5.23 & 6.02 & 6.61 \\
\hline $\mathrm{O}-(\mathrm{H}) \mathrm{CO}$ & -60.78 & 24.30 & 3.88 & 4.98 & 5.80 & 6.34 & 7.17 & 7.75 \\
\hline $\mathrm{O}-(\mathrm{H})\left(\mathrm{C}_{\mathrm{d}}\right)$ & -44.50 & 34.93 & 4.33 & 4.45 & 4.82 & 5.23 & 6.02 & 6.61 \\
\hline $\mathrm{O}-(\mathrm{C}) 2$ & -24.23 & 7.01 & 4.43 & 4.73 & 4.73 & 4.83 & 5.43 & 5.63 \\
\hline $\mathrm{O}-(\mathrm{C})(\mathrm{CO})$ & -45.13 & 8.61 & 2.82 & 3.79 & 4.38 & 4.73 & 4.91 & 5.03 \\
\hline $\mathrm{CO}-(\mathrm{H})(\mathrm{C})$ & -29.72 & 35.13 & 6.93 & 7.87 & 8.82 & 9.68 & 11.16 & 12.20 \\
\hline $\mathrm{CO}-(\mathrm{H})\left(\mathrm{C}_{\mathrm{d}}\right)$ & -30.34 & 35.40 & 5.81 & 7.22 & 9.50 & 11.65 & 15.08 & 17.84 \\
\hline $\mathrm{CO}-(\mathrm{C})(\mathrm{O})$ & -32.79 & 14.96 & 5.87 & 6.70 & 7.45 & 8.02 & 8.87 & 9.36 \\
\hline $\mathrm{CO}-\left(\mathrm{C}_{\mathrm{d}}\right)(\mathrm{O})$ & -32.67 & 14.96 & 5.87 & 6.16 & 7.39 & 7.68 & 8.79 & 9.42 \\
\hline $\mathrm{C}-(\mathrm{H})_{3}(\mathrm{O})$ & -10.10 & 30.42 & 6.15 & 7.84 & 9.40 & 10.79 & 13.02 & 14.77 \\
\hline $\mathrm{C}-(\mathrm{H})_{2}(\mathrm{O})(\mathrm{C})$ & -7.86 & 10.38 & 4.86 & 6.85 & 8.30 & 9.43 & 11.11 & 12.33 \\
\hline $\mathrm{C}-(\mathrm{H})(\mathrm{O})(\mathrm{C})_{2}$ & -7.20 & -11.00 & 4.80 & 6.64 & 8.10 & 8.73 & 9.81 & 10.40 \\
\hline $\mathrm{C}-(\mathrm{H})(\mathrm{O})_{2}(\mathrm{C})$ & -13.81 & -13.10 & 2.22 & 4.45 & 6.72 & 8.07 & 8.71 & 9.09 \\
\hline $\mathrm{C}-(\mathrm{O})(\mathrm{C})_{3}$ & -6.60 & -33.56 & 4.33 & 6.19 & 7.25 & 7.70 & 8.20 & 8.24 \\
\hline $\mathrm{C}-(\mathrm{H})_{2}(\mathrm{CO})(\mathrm{C})$ & -5.22 & 9.46 & 5.90 & 7.70 & 8.70 & 9.50 & 11.10 & 12.20 \\
\hline $\mathrm{C}_{\mathrm{d}}-(\mathrm{O})(\mathrm{H})$ & 8.68 & 7.90 & 4.48 & 5.03 & 5.81 & 6.50 & 7.65 & 8.45 \\
\hline $\mathrm{C}_{\mathrm{d}^{-}}(\mathrm{O})(\mathrm{C})$ & 10.55 & -12.15 & 3.61 & 4.13 & 4.51 & 4.78 & 5.32 & 5.60 \\
\hline $\mathrm{C}_{\mathrm{d}}-(\mathrm{O})(\mathrm{CO})$ & 11.60 & -12.60 & 5.59 & 7.00 & 7.48 & 7.75 & 8.02 & 8.13 \\
\hline $\mathrm{C}_{\mathrm{d}}-(\mathrm{CO})(\mathrm{H})$ & 7.72 & 8.41 & 3.73 & 5.00 & 5.42 & 5.78 & 6.53 & 7.19 \\
\hline $\mathrm{C}_{\mathrm{b}}-(\mathrm{O})$ & -1.14 & -10.45 & 3.79 & 5.30 & 6.20 & 6.60 & 6.90 & 6.90 \\
\hline $\mathrm{C}_{\mathrm{b}}-(\mathrm{CO})$ & 3.70 & -7.70 & 2.67 & 3.14 & 3.68 & 4.15 & 4.96 & 5.44 \\
\hline \multicolumn{9}{|c|}{$\mathrm{CHN}$ and $\mathrm{CHON}$ groups } \\
\hline $\mathrm{C}-(\mathrm{N})(\mathrm{C})(\mathrm{H})_{2}$ & -6.76 & 10.10 & 5.42 & 6.90 & 8.28 & 9.39 & 11.09 & 12.34 \\
\hline $\mathrm{C}-(\mathrm{N})(\mathrm{C})_{2}(\mathrm{H})$ & -3.99 & -15.19 & 4.45 & 5.42 & 6.20 & 6.99 & 8.07 & 8.48 \\
\hline $\mathrm{N}-(\mathrm{C})(\mathrm{H})_{2}$ & 4.80 & 29.71 & 5.72 & 6.51 & 7.32 & 8.07 & 9.41 & 10.47 \\
\hline $\mathrm{N}-(\mathrm{C})_{2}(\mathrm{H})$ & 16.14 & 8.12 & 2.93 & 3.94 & 4.86 & 5.56 & 6.63 & 7.38 \\
\hline $\mathrm{N}-(\mathrm{C})_{3}$ & 27.84 & -14.75 & 3.61 & 4.56 & 5.43 & 5.97 & 6.56 & 6.67 \\
\hline $\mathrm{N}_{\mathrm{i}^{-}}(\mathrm{C})$ & 19.47 & 5.90 & 2.48 & 3.34 & 3.95 & 4.29 & 4.59 & 5.17 \\
\hline $\mathrm{N}_{\mathrm{i}}-\left(\mathrm{C}_{\mathrm{b}}\right)$ & 16.49 & 11.23 & 2.41 & 3.20 & 4.55 & 5.39 & 6.17 & 6.28 \\
\hline $\mathrm{N}_{\mathrm{a}}-(\mathrm{H})$ & 25.10 & 26.80 & 4.38 & 4.89 & 5.44 & 5.94 & 6.77 & 7.42 \\
\hline $\mathrm{N}_{\mathrm{a}}-(\mathrm{C})$ & 26.17 & 8.50 & 2.70 & 4.10 & 4.92 & 5.34 & 5.69 & 5.71 \\
\hline $\mathrm{N}_{\mathrm{a}}-(\mathrm{N})$ & 23.00 & 8.50 & 2.12 & 4.18 & 5.51 & 6.77 & 6.86 & 7.05 \\
\hline $\mathrm{CO}-(\mathrm{N})(\mathrm{H})$ & -29.72 & 35.13 & 6.93 & 7.87 & 8.82 & 9.68 & 11.16 & 12.20 \\
\hline $\mathrm{CO}-(\mathrm{N})(\mathrm{C})$ & -31.84 & 13.55 & 5.38 & 6.17 & 7.07 & 7.66 & 9.62 & 11.19 \\
\hline $\mathrm{N}-(\mathrm{CO})(\mathrm{H})_{2}$ & -14.90 & 24.69 & 4.07 & 5.75 & 7.13 & 8.29 & 9.96 & 11.22 \\
\hline $\mathrm{N}-(\mathrm{CO})(\mathrm{C})(\mathrm{H})$ & -4.40 & 3.90 & 0.66 & 1.55 & 2.46 & 3.48 & 4.24 & 4.53 \\
\hline $\mathrm{N}-(\mathrm{CO})(\mathrm{C})_{2}$ & 10.75 & -16.90 & 3.11 & 4.58 & 5.62 & 6.25 & 6.79 & 6.87 \\
\hline
\end{tabular}




\begin{tabular}{|c|c|c|c|c|c|c|c|c|}
\hline $\mathrm{N}-(\mathrm{CO})_{2}\left(\mathrm{C}_{\mathrm{b}}\right)$ & -2.78 & 15.20 & 1.07 & 3.10 & 4.31 & 5.00 & 5.48 & 6.47 \\
\hline \multicolumn{9}{|c|}{$\mathrm{CCl}$ groups } \\
\hline $\mathrm{C}-(\mathrm{Cl})_{3}(\mathrm{C})$ & -19.59 & 48.30 & 16.30 & 18.00 & 19.10 & 19.80 & 20.60 & 21.00 \\
\hline $\mathrm{C}_{\mathrm{d}}-(\mathrm{Cl})_{2}$ & -2.75 & 41.91 & 11.20 & 12.50 & 13.30 & 13.90 & 14.60 & 15.00 \\
\hline $\mathrm{C}_{\mathrm{b}}-(\mathrm{Cl})$ & -4.07 & 18.42 & 7.01 & 8.40 & 9.20 & 9.70 & 10.20 & 10.40 \\
\hline \multicolumn{9}{|c|}{ COS groups } \\
\hline $\mathrm{C}-(\mathrm{C})(\mathrm{H})_{2}(\mathrm{~S})$ & -5.54 & 10.00 & 4.99 & 7.08 & 8.60 & 9.97 & 12.26 & 14.15 \\
\hline $\mathrm{C}-(\mathrm{C})_{2}(\mathrm{H})(\mathrm{S})$ & -1.41 & -11.32 & 4.85 & 6.51 & 7.78 & 8.69 & 9.90 & 10.57 \\
\hline $\mathrm{C}_{\mathrm{b}}-(\mathrm{S})$ & -1.14 & -10.45 & 3.79 & 5.30 & 6.20 & 6.60 & 6.90 & 6.90 \\
\hline $\mathrm{C}_{\mathrm{d}}-(\mathrm{H})(\mathrm{S})$ & 8.68 & 7.90 & 4.48 & 5.03 & 5.81 & 6.50 & 7.65 & 8.45 \\
\hline $\mathrm{C}_{\mathrm{d}}-(\mathrm{C})(\mathrm{S})$ & 10.93 & -12.41 & 3.50 & 6.36 & 3.83 & 4.09 & 4.41 & 5.00 \\
\hline S-(C)(H) & 4.45 & 32.90 & 6.16 & 6.49 & 6.79 & 7.07 & 7.59 & 8.00 \\
\hline $\mathrm{S}-(\mathrm{C})_{2}$ & 11.23 & 13.19 & 5.41 & 5.39 & 5.45 & 5.50 & 5.84 & 6.16 \\
\hline S- $(C)\left(C_{b}\right)$ & 18.21 & -7.80 & 3.02 & 3.39 & 3.71 & 4.04 & 4.62 & 5.00 \\
\hline $\mathrm{C}_{\mathrm{b}}-(\mathrm{SO})$ & 3.70 & 10.40 & 2.67 & 3.14 & 3.68 & 4.15 & 4.96 & 5.44 \\
\hline
\end{tabular}

${ }^{a} C_{d}$ represents a double-bonded carbon atom, $C_{b}$ a $C$-atom in a benzene ring, $N_{i}$ an imino $N$-atom in $N=C$, $N_{a}$ an azo $N$-atom in $N=N$.

\section{Results and Discussion}

\section{Group optimization}

Using the methodology described previously, thermodynamic data of 190 molecules were estimated from ab initio calculations at the CBS-QB3 level of theory. The set of molecules was chosen to involve all the Benson groups, which appear in the molecules of interest. For each new group, at least three different molecules were calculated. Molecules were chosen as simple as possible in order to reduce calculation time and uncertainties due to conformations and non-bonding effects (steric effect, intramolecular interactions...). The list of the calculated data and the geometry of molecules are given in Supplemental Material. A selection of chemical agents of interest with their calculated parameters is presented in Table 4. Beyond orthophosphoric acid $\mathrm{H}_{3} \mathrm{PO}_{4}$, they are chemical warfare nerve agents as Tabun, and Sarin; nontoxic simulants of nerve agents such as dimethyl methylphosphonate (DMMP) and trimethylphosphonate (TMP), and eventually an herbicide such as Glyphosate. Note that this latter, $\mathrm{C}_{3} \mathrm{H}_{8} \mathrm{NO}_{5} \mathrm{P}$, involves ten heavy atoms and is one of the heaviest molecules calculated here. 
Table 4: Thermochemical properties of some organophosphorus compounds determined at the CBS-QB3 level of theory.

\begin{tabular}{|c|c|c|c|c|c|c|c|c|c|}
\hline \multirow[t]{2}{*}{ Groups $^{a}$} & \multirow{2}{*}{$\begin{array}{c}\Delta_{f} H_{298}^{\circ} \\
\left(\mathrm{kcal} \mathrm{mol}^{-1}\right)\end{array}$} & \multirow{2}{*}{$\begin{array}{c}S_{298}^{\circ} \\
\left(\mathrm{cal} \mathrm{mol}^{-1} \mathrm{~K}^{-1}\right)\end{array}$} & \multicolumn{7}{|c|}{$C_{p}^{\circ}(T)\left(\mathrm{cal} \mathrm{mol}^{-1} \mathrm{~K}^{-1}\right)$} \\
\hline & & & 300 & 400 & 500 & 600 & 800 & 1000 & 1500 \\
\hline $\mathrm{H}_{3} \mathrm{PO}_{4}$ & -272.38 & 79.97 & 23.31 & 26.07 & 28.16 & 29.71 & 31.84 & 33.34 & 35.92 \\
\hline TMP & -254.81 & 106.98 & 36.87 & 43.76 & 49.95 & 55.17 & 63.26 & 69.21 & 78.45 \\
\hline DMMP & -204.55 & 99.98 & 34.21 & 40.87 & 46.92 & 52.02 & 59.84 & 65.51 & 74.23 \\
\hline Sarin & -240.51 & 103.59 & 39.98 & 48.32 & 55.28 & 60.93 & 69.49 & 75.67 & 85.17 \\
\hline Tabun & -115.87 & 120.54 & 47.10 & 56.04 & 63.92 & 70.53 & 80.72 & 88.14 & 99.53 \\
\hline Glyphosate & -298.15 & 118.04 & 45.62 & 54.64 & 62.11 & 68.09 & 76.87 & 82.92 & 91.27 \\
\hline
\end{tabular}

These calculated data enabled the optimization of the value of many new Benson groups. Due to the lack of data for the contribution to heat capacity at $1500 \mathrm{~K}$ of many groups from the literature used as a basis ${ }^{35}$, contributions for new groups could just be derived between $300 \mathrm{~K}$ and $1000 \mathrm{~K}$. The thermodynamic parameters of fifteen molecules were used to optimize six new groups involving the trivalent phosphorus atom. Three groups were also optimized for the monovalent super-atoms -OPO and -OPS, which contain a trivalent $\mathrm{P}$-atom double bonded to $\mathrm{O}$ or $\mathrm{S}$ and can be produced in decomposition products. A super-atom represents a functional group handled as a group with its own valence, such as $\mathrm{CO}$ (valence 2) $-\mathrm{CN}$ (valence 1) or PO (valence 3). The results obtained are presented in Table 5. The description of organophosphorus compounds containing a pentavalent phosphorus atom double bonded to oxygen and bonded to carbon, oxygen and hydrogen atoms requires 14 additional groups, which are listed in Table 6. These results are in reasonable agreement with those published for some groups by Glaude et al. in 200123, which were based on PM3 calculations, considering the difference in the level of the calculations. For instance, the value of the enthalpy for the groups PO- $(\mathrm{C})(\mathrm{O})_{2}$, PO- $(\mathrm{H})(\mathrm{O})_{2}$ and $\mathrm{O}-(\mathrm{C})(\mathrm{PO})$, were -92.7, -91.1, and -36.8 $\mathrm{kcal} \mathrm{mol}^{-1}$, respectively, against $-92.3,-85.6$, and $-40.9 \mathrm{kcal} \mathrm{mol}^{-1}$, respectively, in the present evaluation. When a sulfur atom is bonded to the P-atom in the PO group, twelve new groups could be defined while nine are proposed for compounds containing the super-atom PS (Table 7). Ten groups appeared in the case of compounds, which contain a nitrogen atom or a cyanide $\mathrm{C} \equiv \mathrm{N}$ functional group (Table 8). Eventually, we optimized four new Benson groups containing a fluorine atom bonded to PO (Table 9). 
Several structures, which do not involved phosphorus, but contain unknown groups appear in the molecules of interest, especially in pesticides and herbicides. It occurs in particular for many functional groups containing nitrogen and sulfur. Nineteen groups related to nitrogen-containing molecules and six groups related to sulfur-containing molecules were determined. Results are displayed in Table 10.

For the whole set of calculated molecules, the mean average deviation (MAD) of enthalpies calculated with the GC from the theoretical enthalpies is $0.62 \mathrm{kcal} \mathrm{mol}^{-1}$, with a maximum error of 2.2 $\mathrm{kcal} \mathrm{mol}^{-1}$. Domalski and Hearing ${ }^{62}$ considered after the determination of group values against experimental data that an error below $1 \mathrm{kcal} \mathrm{mol}^{-1}$ showed a very good regression, a deviation between 1 and $2 \mathrm{kcal} \mathrm{mol}^{-1}$ the limit of acceptability, while a difference above $2 \mathrm{kcal} \mathrm{mol}^{-1}$ denoted a specific problem. This will be illustrated below. In the case of entropy, the MAD is $0.92 \mathrm{cal} \mathrm{mol}^{-1} \mathrm{~K}^{-1}$, the two maximum errors in the set of molecules being 3.4 and $2.5 \mathrm{cal} \mathrm{mol}^{-1} \mathrm{~K}^{-1}$, respectively. Finally, the MAD of heat capacities increases slightly with the temperature from $0.41 \mathrm{cal} \mathrm{mol}^{-1} \mathrm{~K}^{-1}$ at $300 \mathrm{~K}$ to $0.48 \mathrm{cal} \mathrm{mol}^{-1} \mathrm{~K}^{-1}$ at $1000 \mathrm{~K}$.

Table 5. Group values for species involving a trivalent P-atom.

\begin{tabular}{|c|c|c|c|c|c|c|c|c|}
\hline \multirow[t]{2}{*}{ Groups $^{a}$} & \multirow{2}{*}{$\begin{array}{c}\Delta_{f} H_{298}^{\circ} \\
\left(\mathrm{kcal} \mathrm{mol}^{-1}\right)\end{array}$} & \multirow{2}{*}{$\begin{array}{c}S_{298}^{\circ} \\
\left(\mathrm{cal} \mathrm{mol} \mathrm{m}^{-1} \mathrm{~K}^{-1}\right)\end{array}$} & \multicolumn{6}{|c|}{$C_{p}^{\circ}(T)\left(\mathrm{cal} \mathrm{mol}^{-1} \mathrm{~K}^{-1}\right)$} \\
\hline & & & 300 & 400 & 500 & 600 & 800 & 1000 \\
\hline $\mathrm{C}-(\mathrm{P})(\mathrm{H})_{3}{ }^{a}$ & -10.098 & 30.42 & 6.15 & 7.84 & 9.40 & 10.79 & 13.02 & 14.77 \\
\hline $\mathrm{O}-(\mathrm{C})(\mathrm{P})$ & -29.87 & 14.27 & 7.39 & 7.98 & 8.61 & 9.14 & 9.98 & 10.48 \\
\hline $\mathrm{O}-(\mathrm{H})(\mathrm{P})$ & -45.40 & 34.61 & 8.89 & 10.17 & 11.10 & 11.75 & 12.61 & 13.16 \\
\hline $\mathrm{P}-(\mathrm{O})_{2}(\mathrm{CN})$ & 5.80 & 8.44 & 5.26 & 5.51 & 5.62 & 5.65 & 5.66 & 5.65 \\
\hline $\mathrm{P}-(\mathrm{CN})(\mathrm{H})(\mathrm{O})$ & 26.04 & 36.25 & 9.03 & 10.17 & 11.05 & 11.73 & 12.76 & 13.46 \\
\hline $\mathrm{P}-(\mathrm{O})_{2}(\mathrm{H})$ & -23.60 & -2.12 & -1.64 & -1.52 & -1.29 & -1.07 & -0.74 & -0.57 \\
\hline OPO- $(\mathrm{C})^{b}$ & -95.79 & 42.16 & 10.58 & 11.41 & 12.31 & 13.03 & 14.04 & 14.59 \\
\hline OPS- $(\mathrm{H})^{c}$ & -46.00 & 68.07 & 13.94 & 15.09 & 15.90 & 16.55 & 17.56 & 18.24 \\
\hline OPS- $(\mathrm{C})^{c}$ & -40.76 & 47.55 & 13.09 & 13.88 & 14.63 & 15.00 & 14.99 & 14.71 \\
\hline
\end{tabular}

${ }^{b}$ Super-atom $-O-P=O$ used in a molecule $R-O-P=O$

${ }^{c}$ Super-atom $O=P$-S- used in a molecule $R-S-P=O$ 
Table 6. Group values for species involving a super-atom $\mathrm{P}=\mathrm{O}$ bonded to $\mathrm{O}, \mathrm{H}$ and $\mathrm{C}$-atoms.

\begin{tabular}{lccrrrrrr}
\hline \multicolumn{1}{c}{ Groups } & $\Delta_{f} H_{298}^{\circ}$ & $S_{298}^{\circ}$ & \multicolumn{5}{c}{$C_{p}^{\circ}(T)\left(\mathrm{cal} \mathrm{mol}^{-1} \mathrm{~K}^{-1}\right)$} \\
\cline { 5 - 9 } & $\left(\mathrm{kcal} \mathrm{mol}^{-1}\right)$ & $\left(\mathrm{cal} \mathrm{mol}^{-1} \mathrm{~K}^{-1}\right)$ & 300 & 400 & 500 & 600 & 800 & 1000 \\
\hline $\mathrm{C}-(\mathrm{PO})(\mathrm{H})_{3}{ }^{a}$ & -10.098 & 30.42 & 6.15 & 7.84 & 9.40 & 10.79 & 13.02 & 14.77 \\
$\mathrm{C}-(\mathrm{PO})(\mathrm{H})_{2}(\mathrm{C})$ & -4.09 & 8.85 & 5.06 & 6.87 & 8.44 & 9.75 & 11.67 & 13.02 \\
$\mathrm{C}-(\mathrm{PO})(\mathrm{H})(\mathrm{O})(\mathrm{C})$ & -3.27 & -12.11 & 5.53 & 7.40 & 8.74 & 9.63 & 10.46 & 10.93 \\
$\mathrm{O}-(\mathrm{H})(\mathrm{PO})$ & -56.90 & 34.66 & 10.84 & 12.50 & 13.67 & 14.50 & 15.50 & 16.08 \\
$\mathrm{O}-(\mathrm{C})(\mathrm{PO})$ & -40.85 & 15.06 & 9.34 & 10.23 & 10.99 & 11.57 & 12.40 & 12.88 \\
$\mathrm{O}-\left(\mathrm{C}_{\mathrm{d}}\right)(\mathrm{PO})$ & -44.03 & 15.59 & 9.92 & 11.22 & 11.85 & 12.22 & 12.53 & 12.82 \\
$\mathrm{O}-\left(\mathrm{C}_{\mathrm{b}}\right)(\mathrm{PO})$ & -35.32 & 19.26 & 8.89 & 9.04 & 9.28 & 9.63 & 10.38 & 11.01 \\
$\mathrm{O}-\mathrm{PO}{ }_{2}-(\mathrm{C})^{b}$ & -154.85 & 49.51 & 14.83 & 16.40 & 17.90 & 18.98 & 20.03 & 20.49 \\
$\mathrm{PO}-(\mathrm{C})(\mathrm{H})(\mathrm{O})$ & -74.95 & 10.66 & 3.76 & 4.46 & 4.94 & 5.39 & 6.10 & 17.88 \\
$\mathrm{PO}-(\mathrm{C})(\mathrm{O})_{2}$ & -92.27 & -17.36 & -1.84 & -2.22 & -2.55 & -2.89 & -3.51 & -3.94 \\
$\mathrm{PO}-(\mathrm{H})(\mathrm{O})_{2}$ & -85.61 & 3.83 & -2.50 & -2.36 & -2.18 & -2.06 & -1.92 & -1.81 \\
$\mathrm{PO}-(\mathrm{C})_{2}(\mathrm{O})$ & -81.07 & -9.73 & 4.68 & 4.74 & 4.62 & 4.40 & 4.12 & 3.87 \\
$\mathrm{PO}-(\mathrm{C})_{3}$ & -69.18 & -1.95 & 11.44 & 12.28 & 12.50 & 12.42 & 12.26 & 12.05 \\
$\mathrm{PO}-(\mathrm{O})_{3}$ & -101.70 & -21.34 & -8.66 & -9.68 & -10.43 & -11.04 & -11.89 & -12.41 \\
\hline
\end{tabular}

${ }^{a}$ Assumed as $C-(C)(H)_{3}$

${ }^{b}-\mathrm{O}-\mathrm{PO}_{2}$ super-atom monovalent. 
Table 7. Group values for species involving a super-atoms $\mathrm{P}=\mathrm{O}$ or $\mathrm{P}=\mathrm{S}$ bonded to $\mathrm{C} / \mathrm{H} / \mathrm{O}$ and $\mathrm{S}$ atoms.

\begin{tabular}{|c|c|c|c|c|c|c|c|c|}
\hline \multirow[t]{2}{*}{ Groups } & \multirow{2}{*}{$\begin{array}{c}\Delta_{f} H_{298}^{\circ} \\
\left(\mathrm{kcal} \mathrm{mol}^{-1}\right)\end{array}$} & \multirow{2}{*}{$\begin{array}{c}S_{298}^{\circ} \\
\left(\mathrm{cal} \mathrm{mol}{ }^{-1} \mathrm{~K}^{-1}\right)\end{array}$} & \multicolumn{6}{|c|}{$C_{p}^{\circ}(T)\left(\mathrm{cal} \mathrm{mol}^{-1} \mathrm{~K}^{-1}\right)$} \\
\hline & & & 300 & 400 & 500 & 600 & 800 & 1000 \\
\hline $\mathrm{PO}-(\mathrm{H})_{2}(\mathrm{~S})$ & -13.91 & 44.94 & 8.46 & 10.36 & 11.41 & 12.51 & 14.03 & 15.19 \\
\hline PO- $(\mathrm{S})(\mathrm{C})(\mathrm{H})$ & -20.01 & 24.09 & 8.83 & 9.90 & 10.66 & 11.16 & 11.86 & 12.26 \\
\hline $\mathrm{PO}-(\mathrm{S})(\mathrm{O})(\mathrm{H})$ & -30.08 & 14.93 & 2.28 & 2.73 & 3.19 & 3.60 & 4.23 & 4.69 \\
\hline $\mathrm{PO}-(\mathrm{O})(\mathrm{S})(\mathrm{C})$ & -36.55 & -6.72 & 3.20 & 3.00 & 2.77 & 2.47 & 1.97 & 1.54 \\
\hline $\mathrm{PO}-(\mathrm{O})_{2}(\mathrm{~S})$ & -46.19 & -10.80 & -3.30 & -3.75 & -4.32 & -4.78 & -5.50 & -5.99 \\
\hline $\mathrm{S}-(\mathrm{PO})(\mathrm{H})$ & -46.13 & 26.72 & 7.89 & 8.82 & 9.41 & 9.81 & 10.40 & 10.83 \\
\hline $\mathrm{S}-(\mathrm{PO})(\mathrm{C})$ & -40.09 & 5.58 & 6.42 & 6.82 & 7.21 & 7.42 & 7.66 & 7.67 \\
\hline $\mathrm{S}-(\mathrm{PO})\left(\mathrm{C}_{\mathrm{d}}\right)$ & -38.62 & 7.75 & 7.23 & 7.53 & 8.79 & 8.88 & 8.71 & 8.45 \\
\hline $\mathrm{S}-\mathrm{PO}_{2}-(\mathrm{H})^{b}$ & -110.70 & 72.67 & 16.65 & 18.61 & 19.94 & 21.00 & 22.54 & 23.53 \\
\hline $\mathrm{S}-\mathrm{PO}_{2}-(\mathrm{C})^{b}$ & -106.69 & 53.87 & 16.17 & 17.44 & 18.54 & 19.27 & 19.98 & 20.22 \\
\hline O-POS- $(\mathrm{H})^{c}$ & -113.80 & 71.89 & 16.34 & 18.52 & 19.99 & 21.04 & 22.33 & 23.03 \\
\hline O-POS- $(\mathrm{C})^{c}$ & -99.00 & 52.23 & 15.78 & 17.23 & 18.40 & 19.33 & 20.17 & 20.50 \\
\hline PS- $(\mathrm{O})_{3}$ & -171.99 & -5.35 & 0.44 & 0.14 & 0.00 & 0.10 & 0.26 & 0.44 \\
\hline $\mathrm{PS}-(\mathrm{O})_{2}(\mathrm{~S})$ & -58.37 & 31.17 & 4.93 & 5.26 & 6.59 & 5.69 & 5.74 & 5.73 \\
\hline $\mathrm{C}-(\mathrm{PS})(\mathrm{H})_{3}$ & -10.10 & 30.42 & 6.15 & 7.84 & 9.40 & 10.79 & 13.02 & 14.77 \\
\hline $\mathrm{S}-(\mathrm{PS})(\mathrm{H})$ & -61.89 & -4.47 & 5.35 & 5.61 & 4.61 & 5.82 & 6.25 & 6.68 \\
\hline $\mathrm{S}-(\mathrm{C})(\mathrm{PS})$ & -56.48 & -22.47 & 4.58 & 4.94 & 4.07 & 5.15 & 4.77 & 4.34 \\
\hline $\mathrm{O}-(\mathrm{H})(\mathrm{PS})$ & -12.82 & 30.25 & 8.62 & 9.62 & 10.24 & 10.61 & 11.06 & 11.38 \\
\hline $\mathrm{O}-(\mathrm{C})(\mathrm{PS})$ & 3.13 & 10.69 & 6.79 & 7.37 & 7.88 & 8.17 & 8.50 & 8.60 \\
\hline $\mathrm{O}-\left(\mathrm{C}_{\mathrm{b}}\right)(\mathrm{PS})$ & 9.26 & 12.39 & 6.46 & 6.88 & 7.42 & 7.86 & 8.24 & 8.47 \\
\hline $\mathrm{O}-(\mathrm{PS})_{2}$ & -136.07 & 3.93 & 10.71 & 12.93 & 14.21 & 14.97 & 15.57 & 15.67 \\
\hline
\end{tabular}

Table 8. Group values for species involving a super-atoms $\mathrm{P}=\mathrm{O}$ bonded to $\mathrm{C} / \mathrm{H} / \mathrm{O}$ and $\mathrm{N}$-atoms.

\begin{tabular}{lccrrrrrr}
\hline \multicolumn{1}{c}{ Groups } & $\Delta_{f} H_{298}^{\circ}$ & $S_{298}^{\circ}$ & \multicolumn{6}{c}{$C_{p}^{\circ}(T)\left(\mathrm{cal} \mathrm{mol}^{-1} \mathrm{~K}^{-1}\right)$} \\
\cline { 5 - 9 } & $\left(\mathrm{kcal} \mathrm{mol}^{-1}\right)$ & $\left(\mathrm{cal} \mathrm{mol}^{-1} \mathrm{~K}^{-1}\right)$ & 300 & 400 & 500 & 600 & 800 & 1000 \\
\hline $\mathrm{N}-(\mathrm{PO})(\mathrm{H})_{2}$ & 10.77 & 37.44 & 8.99 & 10.50 & 11.62 & 12.40 & 13.68 & 14.55 \\
$\mathrm{~N}-(\mathrm{PO})(\mathrm{H})(\mathrm{C})$ & 23.71 & 17.64 & 6.97 & 7.98 & 8.87 & 9.71 & 10.81 & 11.59 \\
$\mathrm{~N}-(\mathrm{PO})(\mathrm{C})_{2}$ & 32.44 & -3.03 & 6.51 & 7.01 & 7.52 & 7.94 & 8.74 & 9.18 \\
$\mathrm{PO}-(\mathrm{N})(\mathrm{O})(\mathrm{H})$ & -99.11 & 0.62 & 0.92 & 1.49 & 2.14 & 2.63 & 3.61 & 4.18 \\
$\mathrm{PO}-(\mathrm{O})_{2}(\mathrm{~N})$ & -114.36 & -24.82 & -5.20 & -6.17 & -6.93 & -7.50 & -8.35 & -8.74 \\
$\mathrm{PO}-(\mathrm{CN})(\mathrm{O})(\mathrm{H})$ & -33.81 & 40.93 & 10.09 & 11.51 & 12.71 & 13.68 & 15.15 & 16.14 \\
$\mathrm{PO}-(\mathrm{CN})(\mathrm{N})(\mathrm{H})$ & -48.30 & 40.63 & 13.86 & 15.69 & 17.06 & 18.13 & 19.71 & 20.79 \\
$\mathrm{PO}-(\mathrm{CN})(\mathrm{N})(\mathrm{O})$ & -68.07 & 10.80 & 7.70 & 8.31 & 8.81 & 9.29 & 9.92 & 10.36 \\
$\mathrm{PO}-(\mathrm{CN})(\mathrm{O})_{2}$ & -51.80 & 12.81 & 4.41 & 4.65 & 4.75 & 4.82 & 4.96 & 5.10 \\
$\mathrm{C}-(\mathrm{PO})(\mathrm{N})(\mathrm{H})_{2}$ & -4.24 & 7.37 & 5.51 & 7.48 & 9.40 & 10.94 & 12.91 & 14.18 \\
\hline
\end{tabular}


Table 9. Group values for species involving a super-atoms $\mathrm{P}=\mathrm{O}$ bonded to $\mathrm{C} / \mathrm{H} / \mathrm{O}$ and $\mathrm{F}$-atoms.

\begin{tabular}{lccrrrrrr}
\hline \multicolumn{1}{r}{ Groups } & $\Delta_{f} H_{298}^{\circ}$ & \multicolumn{6}{c}{$S_{298}^{\circ}$} & \multicolumn{5}{c}{$C_{p}^{\circ}(T)\left(\mathrm{cal} \mathrm{mol}^{-1} \mathrm{~K}^{-1}\right)$} \\
\cline { 4 - 9 } & $\left(\mathrm{kcal} \mathrm{mol}^{-1}\right)$ & $\left(\mathrm{cal} \mathrm{mol}^{-1} \mathrm{~K}^{-1}\right)$ & 300 & 400 & 500 & 600 & 800 & 1000 \\
$\mathrm{PO}-(\mathrm{H})(\mathrm{C})(\mathrm{F})$ & -142.97 & 42.47 & 12.72 & 14.32 & 15.47 & 16.30 & 17.51 & 18.29 \\
$\mathrm{PO}-(\mathrm{H})(\mathrm{O})(\mathrm{F})$ & -153.15 & 34.04 & 6.48 & 7.80 & 8.88 & 9.71 & 10.81 & 11.41 \\
$\mathrm{PO}-(\mathrm{O})_{2}(\mathrm{~F})$ & -169.02 & 6.25 & 0.17 & 0.22 & 0.20 & 0.26 & 0.23 & 0.16 \\
$\mathrm{PO}-(\mathrm{C})(\mathrm{O})(\mathrm{F})$ & -162.06 & 13.74 & 6.60 & 7.19 & 7.50 & 7.78 & 8.05 & 8.18 \\
\hline
\end{tabular}

Table 10. Group values for new $\mathrm{C} / \mathrm{H} / \mathrm{O} / \mathrm{N}$ groups without $\mathrm{P}$-atom.

\begin{tabular}{|c|c|c|c|c|c|c|c|c|}
\hline \multirow[t]{2}{*}{ Groups } & \multirow{2}{*}{$\begin{array}{c}\Delta_{f} H_{298}^{\circ} \\
\left(\mathrm{kcal} \mathrm{mol}^{-1}\right)\end{array}$} & \multirow{2}{*}{ 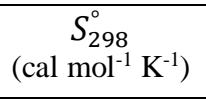 } & \multicolumn{6}{|c|}{$C_{p}^{\circ}(T)\left(\right.$ cal.mol $\left.{ }^{-1} \cdot \mathrm{K}^{-1}\right)$} \\
\hline & & & 300 & 400 & 500 & 600 & 800 & 1000 \\
\hline $\mathrm{N}-\left(\mathrm{C}_{\mathrm{d}}\right)(\mathrm{H})_{2}$ & 4.83 & 31.94 & 5.90 & 6.44 & 6.24 & 7.86 & 8.69 & 9.81 \\
\hline $\mathrm{N}-\left(\mathrm{C}_{\mathrm{d}}\right)(\mathrm{C})_{2}$ & 23.74 & -8.65 & 3.99 & 3.86 & 3.40 & 4.73 & 5.12 & 5.69 \\
\hline $\mathrm{N}_{\mathrm{i}}-(\mathrm{H})^{\mathrm{a}, \mathrm{b}}$ & 7.94 & 25.22 & 3.72 & 5.10 & 5.46 & 6.25 & 7.34 & 8.15 \\
\hline $\mathrm{N}_{\mathrm{i}-}\left(\mathrm{C}_{\mathrm{d}}\right)$ & 16.65 & 10.79 & 2.29 & 3.02 & 4.59 & 5.42 & 6.13 & 6.19 \\
\hline $\mathrm{N}_{\mathrm{i}-}(\mathrm{N})$ & 19.98 & 10.23 & 2.94 & 4.79 & 5.98 & 7.19 & 7.00 & 7.20 \\
\hline $\mathrm{N}-(\mathrm{CO})\left(\mathrm{N}_{\mathrm{i}}\right)(\mathrm{C})$ & 12.30 & -18.77 & 4.50 & 4.24 & 4.38 & 4.17 & 5.21 & 5.42 \\
\hline $\mathrm{C}-(\mathrm{N})(\mathrm{O})(\mathrm{H})_{2}$ & -10.73 & 10.47 & 5.40 & 7.20 & 9.03 & 10.49 & 12.24 & 13.46 \\
\hline $\mathrm{C}-(\mathrm{CO})(\mathrm{N})(\mathrm{H})_{2}$ & -4.84 & 9.28 & 7.08 & 8.68 & 10.24 & 11.62 & 13.27 & 14.46 \\
\hline $\mathrm{C}-(\mathrm{CO})(\mathrm{N})(\mathrm{C})(\mathrm{H})^{\mathrm{a}}$ & -3.69 & -13.17 & 3.67 & 5.32 & 6.89 & 8.37 & 10.01 & 11.14 \\
\hline $\mathrm{C}-\left(\mathrm{N}_{\mathrm{i}}\right)(\mathrm{C})(\mathrm{H})_{2}$ & -1.50 & 12.05 & 5.82 & 7.08 & 8.39 & 9.56 & 11.30 & 12.20 \\
\hline $\mathrm{C}-\left(\mathrm{N}_{\mathrm{i}}\right)(\mathrm{C})_{2}(\mathrm{H})$ & -0.68 & -10.27 & 5.78 & 7.00 & 8.14 & 9.01 & 10.06 & 10.31 \\
\hline $\mathrm{C}_{\mathrm{d}}-(\mathrm{N})(\mathrm{H})$ & 5.24 & 3.71 & 4.35 & 6.05 & 8.32 & 8.37 & 9.89 & 10.48 \\
\hline $\mathrm{C}_{\mathrm{d}}-(\mathrm{N})(\mathrm{C})$ & 5.57 & -15.43 & 3.92 & 5.02 & 6.97 & 6.67 & 7.51 & 7.59 \\
\hline $\mathrm{C}_{\mathrm{d}}-(\mathrm{H})\left(\mathrm{N}_{\mathrm{i}}\right)$ & 14.19 & 3.03 & 5.14 & 6.00 & 6.19 & 6.51 & 7.33 & 8.23 \\
\hline $\mathrm{C}_{\mathrm{b}}-\left(\mathrm{N}_{\mathrm{i}}\right)$ & 10.69 & -12.41 & 4.61 & 5.08 & 4.89 & 4.84 & 4.73 & 5.02 \\
\hline $\mathrm{C}_{\mathrm{b}}-\left(\mathrm{N}_{\mathrm{a}}\right)^{\mathrm{c}}$ & 40.72 & -2.20 & 7.24 & 9.00 & 10.48 & 11.43 & 12.09 & 12.36 \\
\hline $\mathrm{C}_{\mathrm{b}}-\left(\mathrm{NO}_{2}\right)$ & -1.36 & 28.45 & 12.81 & 15.18 & 17.26 & 18.76 & 20.30 & 21.13 \\
\hline $\mathrm{CO}-\left(\mathrm{C}_{\mathrm{d}}\right)(\mathrm{N})^{\mathrm{a}}$ & -30.23 & 15.95 & 8.79 & 9.31 & 10.34 & 11.05 & 11.84 & 12.08 \\
\hline $\mathrm{CO}-\left(\mathrm{C}_{\mathrm{b}}\right)(\mathrm{N})$ & -23.31 & 7.13 & 12.47 & 14.07 & 15.48 & 16.32 & 17.27 & 17.86 \\
\hline $\mathrm{C}-(\mathrm{CO})(\mathrm{S})(\mathrm{C})(\mathrm{H})$ & -2.06 & -12.92 & 5.94 & 7.76 & 9.14 & 10.01 & 10.65 & 10.92 \\
\hline $\mathrm{CS}-(\mathrm{C})(\mathrm{H})^{\mathrm{d}}$ & 27.37 & 37.44 & 8.03 & 8.96 & 9.97 & 10.77 & 11.89 & 12.68 \\
\hline $\mathrm{C}-(\mathrm{CS})(\mathrm{N})(\mathrm{H})_{2}$ & -4.64 & 9.65 & 6.44 & 8.56 & 10.31 & 11.62 & 13.17 & 14.17 \\
\hline $\mathrm{C}-(\mathrm{N})(\mathrm{S})(\mathrm{H})_{2}$ & -8.36 & 8.29 & 6.14 & 8.21 & 10.02 & 11.36 & 12.81 & 13.72 \\
\hline $\mathrm{C}-(\mathrm{S})_{2}(\mathrm{H})_{2}{ }^{\mathrm{a}}$ & -6.89 & 10.39 & 6.04 & 7.79 & 9.02 & 9.94 & 12.23 & 13.77 \\
\hline SO- $\left(\mathrm{C}_{\mathrm{b}}\right)(\mathrm{C})^{\mathrm{a}}$ & -11.98 & -2.56 & 10.20 & 11.60 & 12.21 & 12.33 & 12.05 & 11.64 \\
\hline
\end{tabular}

${ }^{a}$ Group already available, reevaluated. In the case of $C O-\left(C_{d}\right)(N)$ and $C-(C O)(N)(C)(H)$, enthalpy contributions were deduced from an experimental value for L-serine ${ }^{48}$, and from data by Domalski and Hearing ${ }^{62}$, respectively.

Entropy and heat capacities were optimized from theoretical calculations as for other groups.

${ }^{b} N_{i}$ imino in $N=C$.

${ }^{c} N_{a}$ azo in $N=N$.

${ }^{d} C S$ super-atom $C=S$, divalent. 


\section{Evaluation of data calculated by GC}

If thermochemical properties determined from the ab initio calculations would be preferred, using the new Benson groups, the enthalpies of formation $\left(\Delta_{f} H_{298}^{\circ}\right)$, standard entropies $\left(S_{298}^{\circ}\right)$ and heat capacities $\left(C_{p}^{\circ}(T)\right)$ of most of organophosphorus can be calculated easily and quickly by GC. Table 11 presents the thermochemical data of a selection of species containing phosphorus calculated this way. The structure of molecules and their activity are given in the Supplemental Material. Species theoretically investigated (Table 4) were calculated by GC for comparison. In the case of the first molecules, orthophosphoric acid, TMP, DMMP, sarin, and tabun, results agree very well with that obtained theoretically and displayed in Table 4. VX, a nerve agent, was another example to check the quality of the GC method in the evaluation of thermochemical data of larger molecules more difficult to describe theoretically. VX contains 16 heavy atoms and was the heaviest molecule, which energy was calculated by means of $a b$ inito calculations in this work. Since entropy and heat capacity were not evaluated with the same procedure as other chemicals, theoretical data for VX were not displayed in Table 4 and this molecule was not used in the determination of the GC values. VX decomposes in fifteen groups : five $\mathrm{C}-(\mathrm{H})_{3}(\mathrm{C})$, two $\mathrm{C}-(\mathrm{H})(\mathrm{C})_{2}(\mathrm{~N}), \mathrm{N}-(\mathrm{C})_{3}, \mathrm{C}-(\mathrm{H})_{2}(\mathrm{C})(\mathrm{N}), \mathrm{C}-(\mathrm{H})_{2}(\mathrm{C})(\mathrm{S}), \mathrm{S}-(\mathrm{PO})(\mathrm{C})$, $\mathrm{C}-(\mathrm{H})_{3}(\mathrm{PO}), \mathrm{PO}-(\mathrm{S})(\mathrm{C})(\mathrm{O}), \mathrm{O}-(\mathrm{PO})(\mathrm{C}), \mathrm{C}-(\mathrm{H})_{2}(\mathrm{O})(\mathrm{C})$. The enthalpy of formation obtained by $\mathrm{GC}$ is equal to $-178.38 \mathrm{kcal} \mathrm{mol}^{-1}$ and the same calculated theoretically with the CBS-QB3 method is equal to $-179.20 \mathrm{kcal} \mathrm{mol}^{-1}$, so a difference of $0.82 \mathrm{kcal} \mathrm{mol}^{-1}$, below the threshold of $1 \mathrm{kcal} \mathrm{mol}^{-1}$ often considered as the "chemical accuracy" 39 . Due to the large size of the molecule, entropy and heat capacity were not corrected for hindered rotors as for other molecules. Values were evaluated with the harmonic oscillator assumption, to $161.5 \mathrm{cal} \mathrm{mol}^{-1} \mathrm{~K}^{-1}$ and $81.7 \mathrm{cal} \mathrm{mol}^{-1} \mathrm{~K}^{-1}$, respectively for $S^{\circ}$ and $c_{p}^{\circ}$ at $300 \mathrm{~K}$. GC values are $170.1 \mathrm{cal} \mathrm{mol}^{-1} \mathrm{~K}^{-1}$ and $83.64 \mathrm{cal} \mathrm{mol}^{-1} \mathrm{~K}^{-1}$, respectively. The difference comes mainly from the contribution of hindered rotors, which were taken into account in the molecules used for the determination of the new GC data, but not for VX.

Glyphosate, a very widely used herbicide, represents another interesting case for comparison. Its thermochemical properties were determined theoretically (Table 4) with the methodology described above, and by GC in Table 11. Entropy and heat capacity obtained by GC agree fairly well with the theoretical values: $116.0 \mathrm{cal} \mathrm{mol}^{-1} \mathrm{~K}^{-1}$ against $118.04 \mathrm{cal} \mathrm{mol}^{-1} \mathrm{~K}^{-1}$ for $S^{\circ}$, and $45.12 \mathrm{cal} \mathrm{mol}^{-1} \mathrm{~K}^{-1}$ against $45.62 \mathrm{cal} \mathrm{mol}^{-1} \mathrm{~K}^{-1}$ for $C_{p}^{\circ}$ at $300 \mathrm{~K}$. A larger discrepancy appears for the enthalpy of formation: $-292.58 \mathrm{kcal} \mathrm{mol}^{-1}$ by GC against $-298.15 \mathrm{kcal} \mathrm{mol}^{-1}$ theoretically, i.e. a $5.57 \mathrm{kcal} \mathrm{mol}^{-1}$ difference, 
much higher than any difference observed in the set of 190 molecules used for the determination of the group contributions. This can be explained mainly by intramolecular interactions, which stabilize the most stable conformer of glyphosate and cannot be taken into account in the GC method, such as internal hydrogen bonding. In the case of small species in the data set, the number of heteroatoms and the size of the lateral chains bonded to P-atom was smaller, and consequently the occurrence of intramolecular H-bonding was scarcer. The Benson GC method is considered as a third order $\operatorname{method}^{39}$, which uses first order contributions of functional groups, second order structural information such as ring strain, and third order contribution such as non-bonding interactions (e.g. 1,4 gauche interactions), but some structural information are not taken into account, in particular possible intramolecular H-bonds. In some molecules, H-bonds can be formed between different functional groups, lowering the energy of the conformer. This stabilization effect in not included in the group values, and the GC method does not account for. By comparison, the conformer bearing a linear "all trans" side chain, as drawn in Figure 1, does not allow the formation of this intramolecular H-bond and has an enthalpy of formation of $-293.19 \mathrm{kcal} \mathrm{mol}^{-1}$, from which the GC value deviates only by $0.61 \mathrm{kcal} \mathrm{mol}^{-1}$. The entropy of the "all trans" conformer is $122.32 \mathrm{cal} \mathrm{mol} \mathrm{K}{ }^{-1}$, above that of the most stable conformer since the contribution of hindered rotations increase thanks to the lowering of the energy barriers.

It is interesting to examine in more details hydrogen bonding in glyphosate most stable and "alltrans" conformations. The theory of Atom In Molecules (AIM) ${ }^{63}$, based on a topological analysis of the electron density, is an efficient tool to assess intra-molecular bond formation. In this study, we used the AIM2000 program ${ }^{64}$ to qualitatively explore the hydrogen bonding patterns in the two abovementioned conformers of glyphosate. Figure 3 presents the molecular graphs obtained from the AIM analysis applied to the most stable (Figure 3a) and the "all-trans" (Figure 3b) conformations. Note that AIM calculations were performed on glyphosate geometries optimized at the B3LYP/cbsb7 level of theory. The same level of theory was used for the calculation of the Kohn-Sham "wave functions". 

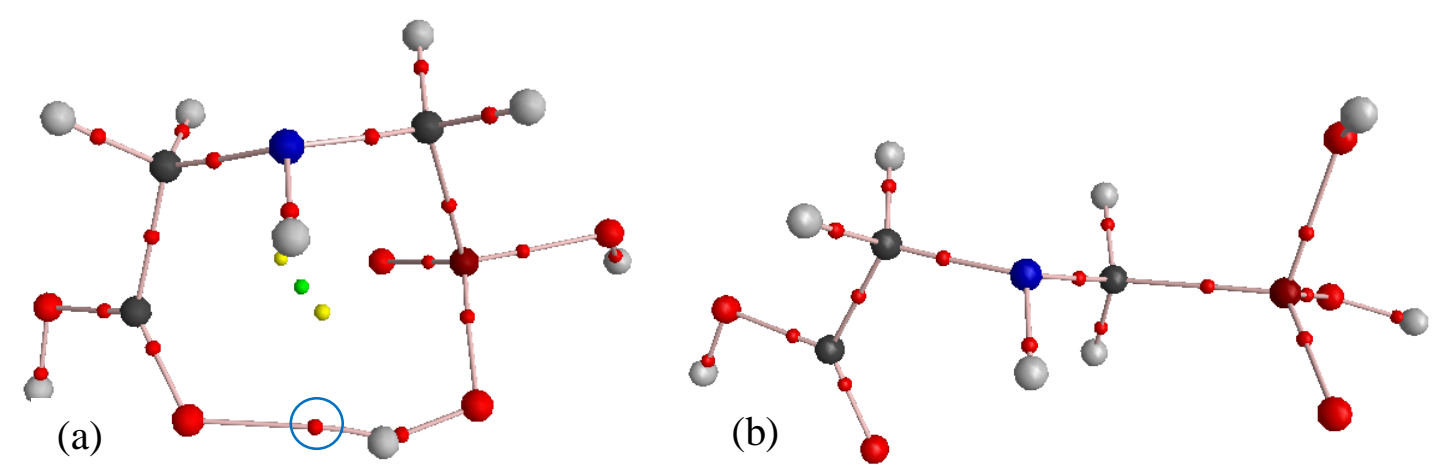

Figure 3. Molecular graphs obtained from the AIM analysis. (a) most stable conformer of glyphosate, (b) "all-trans" conformation.

Within the framework of the AIM theory, different critical points can be identified in a molecular graph. Bond critical point (BCP) are localized on bond paths that connect two atoms. When bond paths connect atoms in a cycle, a ring critical point (RCP) is defined. A cage critical points (CCP) appears when several rings form a cage. As shown in Figure 3a, three types of critical points are found in the most stable conformation of glyphosate: 18 BCP (red), 2 RCP (yellow) and 1 CCP (green). On the other hands, only 17 BCP are identified in the "all-trans" conformation of glyphosate (Figure 3b). The AIM analysis clearly shows that a hydrogen bond exists between the oxygen atom of the $\mathrm{C}=\mathrm{O}$ group and the hydrogen atom of the $\mathrm{P}-\mathrm{OH}$ group in the most stable conformation of glyphosate (BCP highlighted with a blue circle in Figure 3a). The value of the electron density $\rho$ at the hydrogen bond BCP $(\rho=0.027)$ is close to that calculated in 1,3-propanediol ${ }^{65}$ using a similar level of theory. In the all-trans conformation, no hydrogen bond was found and the number of BCP is equal to the number of covalent bonds in glyphosate (17). Further topological analysis of the electron density is beyond the scope of this study. However, we note here a peculiar behavior of the electron density topology characterized by the appearance of a cage critical point in the lowest energy conformation of glyphosate. A first example of the appearance of a cage critical point in a single ring was reported in $2005^{66}$, and glyphosate seems to feature a similar particularity.

The AIM analysis clearly established that a hydrogen bond favors in the most stable conformation. However, it is worth noting that glyphosate has many rotational conformers, some of which having no hydrogen bonding. Recent studies performed by Truhlar and coworkers ${ }^{67-69}$ have shown that consideration of all the rotamers of a given molecule can modify the thermodynamic data obtained, 
compared to the lower energy conformation strategy. In the case of glyphosate, more than five hundred conformations can be generated (some of them being identical or optical isomers) and if the multistructural approach is beyond the scope of this study, it may be assumed that the "correct value" falls somewhere between the previous theoretical calculation and the GC estimation.

As an illustration of the GC method, thermochemical properties of many other chemicals were evaluated, such as a nerve agent (soman), herbicides (glufosinate), and many common insecticides, acaricides, nematicides or fungicides (malathion, methyl parathion, fenthion, mevinphos, dichlorvos, sulfotep, metrifonate, fenamiphos, methyl tolclofos, phorate, phosmet, monocrotophos, fensulfothion). Some of them are use as active in commercial products (e.g. fenamiphos, methyl tolchlofos, phosmet), while many others are now prohibited in European Union or United States, but still in use in many countries as insecticides or acaricides for culture preservation and crop conservation ${ }^{4}$. More specific usages exist in forestry to destroy nematodes ${ }^{70}$ or against head lice infestation (e.g. malathion) ${ }^{71}$. 
Table 11. Thermodynamic properties of organophosphorus chemicals calculated from Group Contribution.

\begin{tabular}{lccrrrrrr}
\hline & $\Delta_{f} H_{298}^{\circ}$ & $S_{298}^{\circ}$ & \multicolumn{7}{c}{$C_{p}^{\circ}(T)\left(\mathrm{cal} \mathrm{mol}^{-1} \mathrm{~K}^{-1}\right)$} \\
\cline { 5 - 9 }$\left(\mathrm{kcal} \mathrm{mol}^{-1}\right)$ & $\left(\mathrm{cal} \mathrm{mol}^{-1} \mathrm{~K}^{-1}\right)$ & 300 & 400 & 500 & 600 & 800 & 1000 \\
\hline $\mathrm{H}_{3} \mathrm{PO}_{4}$ & -272.41 & 80.47 & 23.87 & 27.82 & 30.58 & 32.47 & 34.62 & 35.83 \\
$\mathrm{TMP}$ & -254.55 & 106.39 & 37.80 & 44.53 & 50.74 & 56.05 & 64.39 & 70.54 \\
DMMP & -204.27 & 97.49 & 35.29 & 41.76 & 47.63 & 52.62 & 60.36 & 66.12 \\
Sarin & -240.40 & 103.91 & 39.19 & 47.58 & 54.79 & 60.45 & 69.33 & 75.77 \\
Soman & -257.30 & 123.86 & 55.44 & 69.39 & 80.95 & 90.15 & 104.14 & 114.07 \\
Tabun & -114.64 & 119.30 & 46.86 & 55.91 & 63.82 & 70.61 & 81.23 & 89.06 \\
VX & -178.38 & 170.10 & 83.64 & 103.32 & 120.38 & 134.94 & 157.31 & 173.16 \\
Glyphosate & -292.58 & 116.00 & 45.12 & 54.56 & 62.54 & 68.59 & 76.34 & 81.33 \\
Glufosinate & -238.21 & 108.33 & 48.56 & 59.84 & 69.38 & 77.08 & 88.06 & 95.71 \\
Malathion & -327.82 & 208.85 & 86.63 & 106.45 & 122.12 & 134.22 & 151.12 & 162.92 \\
Parathion & -181.68 & 168.46 & 72.10 & 89.39 & 103.88 & 115.31 & 131.12 & 141.99 \\
Fenthion & -164.62 & 156.49 & 65.08 & 79.30 & 91.71 & 102.00 & 117.22 & 128.10 \\
Sulfotep & -539.36 & 189.09 & 82.77 & 101.46 & 116.52 & 128.75 & 146.60 & 159.38 \\
Mervinphos & -263.72 & 203.47 & 71.31 & 84.33 & 97.21 & 107.36 & 123.52 & 135.54 \\
Dichlorvos & -244.46 & 170.56 & 59.11 & 67.71 & 74.61 & 80.21 & 88.34 & 94.16 \\
Metrifonate & -255.11 & 133.67 & 55.30 & 63.76 & 70.89 & 76.49 & 84.41 & 89.89 \\
Fenamifos & -196.92 & 178.31 & 80.06 & 98.71 & 114.65 & 128.31 & 149.17 & 164.31 \\
Methyl tolclofos & -183.78 & 152.73 & 65.56 & 79.08 & 90.24 & 99.10 & 111.56 & 120.06 \\
Phorate & -154.59 & 169.15 & 67.70 & 82.43 & 94.29 & 103.83 & 119.13 & 130.33 \\
Phosmet & -157.43 & 153.73 & 85.89 & 104.12 & 119.72 & 131.26 & 146.46 & 157.25 \\
Monocrotophos & -261.69 & 151.42 & 61.32 & 73.35 & 83.73 & 92.58 & 105.46 & 114.65 \\
Fensulfothion & -190.42 & 177.47 & 78.31 & 96.79 & 111.90 & 123.82 & 140.85 & 152.71 \\
\hline & & & & & & & &
\end{tabular}

\section{Bond dissociation energies in organophosphorus compounds}

From the enthalpies of formation of molecules and free radicals calculated theoretically, some bond dissociation energies (BDE) of interest molecules like sarin (Figure 4) and tabun (Figure 5) were determined. For example, using the enthalpies of formation of sarin and of the two radicals $\cdot \mathrm{P}=\mathrm{O}(\mathrm{F})\left(\mathrm{CH}_{3}\right)$ and $\cdot \mathrm{OCH}\left(\mathrm{CH}_{3}\right)_{2}$, we evaluate the energy of simple bond $\mathrm{P}-\mathrm{O}$ in sarin which correspond to the enthalpy of reaction (eq.(2)) namely $\Delta_{r} H_{298}^{\circ}=115.20 \mathrm{kcal} \mathrm{mol}^{-1}$. In sarin, the strongest bond is the P-F bond with an energy as high as $143.2 \mathrm{kcal} \mathrm{mol}^{-1}$ (Fig. 4). The PF group has a stabilizing effect on $\beta$-bonds, particularly on $\mathrm{C}-\mathrm{O}$ bond, which $\mathrm{BDE}$ increased by $16.3 \mathrm{kcal} \mathrm{mol}^{-1}$ in comparison to the $\mathrm{BDE}$ of the similar bond in $\mathrm{CH}_{3} \mathrm{COC}_{2} \mathrm{H}_{5}{ }^{72}$. According to these results, the most favored unimolecular 
initiations of sarin are the C-C and P-C bond breakings, which have respectively BDE equal to 92.2 $\mathrm{kcal} \mathrm{mol}^{-1}$ and $96.1 \mathrm{kcal} \mathrm{mol}^{-1}$. The tabun contains a $\mathrm{C} \equiv \mathrm{N}$ group bonded to the PO pattern instead of a fluorine atom (Fig. 5) and the P-CN bond is much lower than P-F. In addition, the $\mathrm{C} \equiv \mathrm{N}$ group tends to decrease the BDE of C-O, which becomes equal to the $\mathrm{C}-\mathrm{O}$ bond energy in $\mathrm{CH}_{3} \mathrm{COC}_{2} \mathrm{H}_{5}{ }^{72}$. For this molecule, the $\mathrm{C}-\mathrm{O}$ bond breaking would be favored $\left(85.0 \mathrm{kcal} \mathrm{mol}^{-1}\right)$.

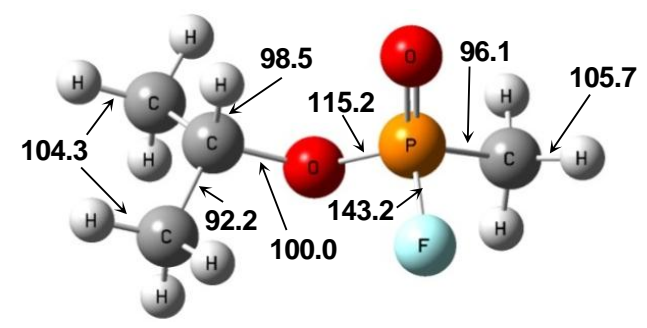

Figure 4. Bond dissociation energies in Sarin, calculated at the CBS-QB3 level (kcal/mol)

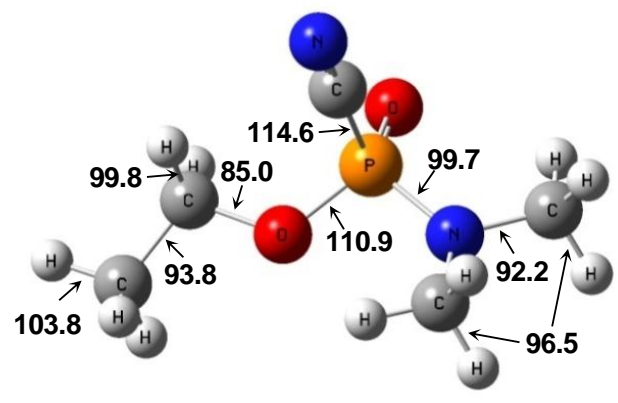

Figure 5. Bond dissociation energies in Tabun, calculated at the CBS-QB3 level (kcal/mol) 


\section{Conclusions}

Calculations of thermodynamic properties of 190 organophosphorus compounds were performed by using ab itinio calculations. The CBS-QB3 level of theory gives a good compromise between accuracy and computational time, and was found to deviate from an experimental set of enthalpies of formation of phosphorus containing species by less than $2 \mathrm{kcal} \mathrm{mol}^{-1}$. This method gives better results than the G4 composite method with shorter calculation times, and shows a deviation by $1.56 \mathrm{kcal} \mathrm{mol}^{-}$

${ }^{1}$ from the high accuracy W1U method, which can be implemented only for very light molecules. From the systematic calculation of the large number of enthalpies of formation $\left(\Delta_{f} H_{298}^{\circ}\right)$, standard entropies $\left(S_{298}^{\circ}\right)$ and heat capacities $\left(C_{p}^{\circ}(T)\right)$, eighty-three Benson groups were optimized. From these new Benson's groups, it is possible to estimate thermochemical data for molecular systems containing a trivalent or pentavalent phosphorus atom bonded to carbon, oxygen, nitrogen, sulphur, and fluorine atoms. The Benson group additivity method allows a fast and accurate determination of thermochemical data particularly useful in the case of heavy organophosphorous molecules, which are common in many agricultural and pest control products. Several bond dissociation energies were also evaluated which are critical to model correctly the thermal decomposition or combustion of organophosphorous compounds.

\section{Acknowledgements}

This work was supported by DGA Maîtrise NRBC. This work was granted access to the HPC resources of CINES under the allocation c2015087249 made by GENCI. The authors thank Dr. M. Ruiz Lòpez at the SRSMC laboratory of the Université de Lorraine for advices and helpful discussions.

\section{Supporting Information}

In supplemental are provided the thermochemical properties and the geometry of all the molecules theoretically studied, and the structure of the molecules of interest, which properties were calculated by GC. This material is available free of charge via the Internet at http://pubs.acs.org 


\section{References}

(1) Munro, N. B.; Ambrose, K. R.; Watson, A. P. Toxicity of the Organophosphate Chemical Warfare Agents GA, GB, and VX: Implications for Public Protection. Environ. Health Perspect. 1994, 102 (1), 18-38.

(2) Brown, M. A.; Brix, K. A. Review of Health Consequences from High-, Intermediate- and Low-Level Exposure to Organophosphorus Nerve Agents. J. Appl. Toxicol. 1998, 18 (6), 393408.

(3) Kwong, T. C. Organophosphate Pesticides: Biochemistry and Clinical Toxicology. Ther. Drug Monit. 2002, 24 (1), 144-149.

(4) University of Hertfordshire (2013) The Pesticide Properties DataBase (PPDB) developed by the Agriculture \& Environment Research Unit (AERU), University of Hertfordshire, 20062013. http://sitem.herts.ac.uk/aeru/ppdb/en/index.htm (accessed Mar 9, 2015).

(5) Gamlin, J.; Romo, P. D.; Hesketh, T. Exposure of Young Children Working on Mexican Tobacco Plantations to Organophosphorous and Carbamic Pesticides, Indicated by Cholinesterase Depression. Child Care Health Dev. 2007, 33 (3), 246-248.

(6) Chen, K.; Mackie, J. C.; Kennedy, E. M.; Dlugogorski, B. Z. Determination of Toxic Products Released in Combustion of Pesticides. Prog. Energy Combust. Sci. 2012, 38, 400-418.

(7) Glaude, P. A.; Melius, C.; Pitz, W. J.; Westbrook, C. K. Detailed Chemical Kinetic Reaction Mechanisms for Incineration of Organophosphorus and Fluoroorganophosphorus Compounds. Proc. Combust. Inst. 2002, 29 (2), 2469-2476.

(8) Sullivan, P. A.; Sumathi, R.; Green, W. H.; Tester, J. W. Ab Initio Modeling of Organophosphorus Combustion Chemistry. Phys. Chem. Chem. Phys. 2004, 6 (17), 42964309.

(9) Gurvich, L. V.; Veyts, I. V.; Alcock, C. B. Thermodynamic Properties of Individual Substances (4th Edn.); Hemisphere: New York, 1989.

(10) Chase, M. W. NIST-JANAF Themochemical Tables, Fourth Edition. J Phys Chem Ref Data 1998, Monograph 9, 1-1951.

(11) Kirklin, D. R.; Domalski, E. S. Energy of Combustion of Triphenylphosphate. J. Chem. Thermodyn. 1989, 21 (5), 449-456.

(12) Kirklin, D. R.; Chickos, J. S.; Liebman, J. F. Enthalpy of Formation of Triphenylphosphine Sulfide. Struct. Chem. 1996, 7 (5-6), 355-361.

(13) Ewig, C. S.; Van Wazer, J. R. Ab Initio Structures of Phosphorus Acids and Esters. 1. Phosphinic, Phosphonic, and Phosphoric Acids. J. Am. Chem. Soc. 1985, 107 (7), 1965-1971.

(14) Leyssens, T.; Peeters, D. Theoretical Study of the Properties of Phosphonate. J. Mol. Struct. THEOCHEM 2004, 673 (1-3), 79-86.

(15) Nam, P.-C.; Nguyen, M. T.; Chandra, A. K. Effect of Substituents on the P-H Bond Dissociation Enthalpies of Phenylphosphines and Proton Affinities of Phenylphosphine Anions: A DFT Study. J. Phys. Chem. A 2004, 108 (51), 11362-11368.

(16) Leroy, G.; Riffi Temsamani, D.; Wilante, C.; Dewispelaere, J.-P. Determination of Bond Energy Terms in Phosphorus Containing Compounds. J. Mol. Struct. THEOCHEM 1994, 309 (2), 113-119.

(17) Borisenko, K. B.; Rankin, D. W. H. Structural Changes, P-P Bond Energies, and Homolytic Dissociation Enthalpies of Substituted Diphosphines from Quantum Mechanical Calculations. Inorg. Chem. 2003, 42 (22), 7129-7136. 
(18) Ho, P.; Melius, C. F. A Theoretical Study of the Thermochemistry of SiFn and SiHnFm Compounds and Si2F6. J. Phys. Chem. 1990, 94 (12), 5120-5127.

(19) Anantharaman, B.; Melius, C. F. Bond Additivity Corrections for G3B3 and G3MP2B3 Quantum Chemistry Methods. J. Phys. Chem. A 2005, 109 (8), 1734-1747.

(20) Bauschlicher, C. W. Heats of Formation for POn and POnH $(\mathrm{n}=1-3)$. J. Phys. Chem. A 1999, 103 (50), 11126-11129.

(21) Haworth, N. L.; Bacskay, G. B. Heats of Formation of Phosphorus Compounds Determined by Current Methods of Computational Quantum Chemistry. J. Chem. Phys. 2002, 117 (24), $11175-11187$.

(22) Haworth, N. L.; Bacskay, G. B.; Mackie, J. C. The Role of Phosphorus Dioxide in the H $+\mathrm{OH}$ Recombination Reaction: Ab Initio Quantum Chemical Computation of Thermochemical and Rate Parameters. J. Phys. Chem. A 2002, 106 (8), 1533-1541.

(23) Glaude, P. A.; Curran, H. J.; Pitz, W. J.; Westbrook, C. K. Kinetic Study of the Combustion of Organophosphorus Compounds. Proc. Combust. Inst. 2000, 28 (2), 1749-1756.

(24) Stewart, J. J. P. Optimization of Parameters for Semiempirical Methods I. Method. J. Comput. Chem. 1989, 10 (2), 209-220.

(25) Montgomery, J.; Ochterski, J.; Petersson, G. A Complete Basis-Set Model Chemistry .4. an Improved Atomic Pair Natural Orbital Method. J. Chem. Phys. 1994, 101 (7), 5900-5909.

(26) Ochterski, J. W.; Petersson, G. A.; Montgomery, J. A. A Complete Basis Set Model Chemistry .5. Extensions to Six or More Heavy Atoms. J. Chem. Phys. 1996, 104 (7), 2598-2619.

(27) Dorofeeva, O. V.; Moiseeva, N. F. Computational Study of the Thermochemistry of Organophosphorus(III) Compounds. J. Phys. Chem. A 2006, 110 (28), 8925-8932.

(28) Dorofeeva, O. V.; Ryzhova, O. N.; Zverev, V. G. Computational Study of the Thermodynamic Properties of organophosphorus(V) Compounds. J. Mol. Struct. THEOCHEM 2007, 811 (1-3), 267-279.

(29) Morgon, N. H. Enthalpies of Formation of Phosphorus and Oxygen Compounds Determined by the Correlation Consistent Composite Approach. Int. J. Quantum Chem. 2012, 112 (19), 3256-3260.

(30) Rey-Villaverde, R.; Cybulski, H.; Flores, J. R.; Fernández, B. A High-Accuracy Theoretical Study of the CHnP Systems N=1-3. J. Comput. Chem. 2013, 34 (23), 2020-2031.

(31) Zhu, L.; Bozzelli, J. W. The Multi-Channel Reaction of CH3S+O-3(2): Thermochemistry and Kinetic Barriers. J. Mol. Struct.-Theochem 2005, 728 (1-3), 147-157.

(32) Zheng, X.; Fisher, E. M.; Gouldin, F. C.; Zhu, L.; Bozzelli, J. W. Experimental and Computational Study of Diethyl Sulfide Pyrolysis and Mechanism. Proc. Combust. Inst. 2009, 32, 469-476.

(33) Head-Gordon, M.; Pople, J. A.; Frisch, M. J. MP2 Energy Evaluation by Direct Methods. Chem. Phys. Lett. 1988, 153 (6), 503-506.

(34) Montgomery, J.; Frisch, M. J.; Ochterski, J. W.; Petersson, G. A. A Complete Basis Set Model Chemistry. VI. Use of Density Functional Geometries and Frequencies. J. Chem. Phys. 1999, 110 (6), 2822-2827.

(35) Benson, S. W. Thermochemical Kinetics, 2d Ed.; Wiley: New York, 1976.

(36) Joback, K. G.; Reid, R. C. Estimation of Pure-Component Properties from GroupContributions. Chem. Eng. Commun. 1987, 57 (1-6), 233-243.

(37) Marrero, J.; Gani, R. Group-Contribution Based Estimation of Pure Component Properties. Fluid Phase Equilibria 2001, 183-184, 183-208. 
(38) Dorofeeva, O. V.; Ryzhova, O. N.; Moiseeva, N. F. The Quantum-Chemical Determination of Group Contributions to the Thermodynamic Properties of Organophosphorus Compounds. Russ. J. Phys. Chem. Focus Chem. 2008, 82 (6), 933-937.

(39) van Speybroeck, V.; Gani, R.; Meier, R. J. The Calculation of Thermodynamic Properties of Molecules. Chem. Soc. Rev. 2010, 39 (5), 1764-1779.

(40) Frisch, M.; Trucks, G.; Schlegel, H.; Scuseria, G.; Robb, M.; Cheeseman, J.; Scalmani, G.; Barone, V.; Mennucci, B.; Petersson, G.; et al. Gaussian 09 Revision C.01.

(41) Petersson, G. A.; Malick, D. K.; Wilson, W. G.; Ochterski, J. W.; Jr, J. A. M.; Frisch, M. J. Calibration and Comparison of the Gaussian-2, Complete Basis Set, and Density Functional Methods for Computational Thermochemistry. J. Chem. Phys. 1998, 109 (24), 10570-10579.

(42) Cox, J. D.; Wagman, D. .; Medvedev, V. A. CODATA Key Values for Thermodynamics; Hemisphere: New York, 1989.

(43) Johnson III, R. D. NIST Computational Chemistry Comparison and Benchmark Database NIST Standard Reference Database Number 101, Release 16a http://cccbdb.nist.gov/ (accessed Mar 13, 2015).

(44) Mokrushin, V.; Tsang, W. Chemrate v.1.5.2; NIST, Ed. Gaithersburg, MD 20899, U.S.A., 2006.

(45) Curtiss, L. A.; Redfern, P. C.; Raghavachari, K. Gaussian-4 Theory. J. Chem. Phys. 2007, 126 (8), 084108.

(46) Martin, J. M. L.; Oliveira, G. de. Towards Standard Methods for Benchmark Quality Ab Initio thermochemistry-W1 and W2 Theory. J. Chem. Phys. 1999, 111 (5), 1843-1856.

(47) Barnes, E. C.; Petersson, G. A.; Montgomery, J. A.; Frisch, M. J.; Martin, J. M. L. Unrestricted Coupled Cluster and Brueckner Doubles Variations of W1 Theory. J. Chem. Theory Comput. 2009, 5 (10), 2687-2693.

(48) Mallard, W.; Lindstrom, P. NIST Chemistry WebBook, NIST Standard Reference Database Number 69.

(49) Burcat, A.; Goos, E.; Ruscic, B. Third Millennium Ideal Gas and Condensed Phase Thermochemical Database for Combustion http://garfield.chem.elte.hu/Burcat/burcat.html.

(50) Drowart, J.; Myers, C. E.; Szwarc, R.; Auwera-Mahieu, A. V.; Uy, O. M. Determination by the Mass Spectrometric Knudsen Cell Method of the Atomization Energies of the Molecules PO and PO2. J. Chem. Soc. Faraday Trans. 2 Mol. Chem. Phys. 1972, 68 (0), 1749-1757.

(51) Hildenbrand, D. L.; Lau, K. H. Thermochemical Properties of Gaseous POBr and Some H-PO Species. J. Chem. Phys. 1994, 100 (11), 8373-8376.

(52) Becke, A. A New Mixing of Hartree-Fock and Local Density-Functional Theories. J. Chem. Phys. 1993, 98 (2), 1372-1377.

(53) Lee, C.; Yang, W.; Parr, R. G. Development of the Colle-Salvetti Correlation-Energy Formula into a Functional of the Electron Density. Phys. Rev. B 1988, 37 (2), 785-789.

(54) Pitzer, K. S.; Gwinn, W. D. Energy Levels and Thermodynamic Functions for Molecules with Internal Rotation I. Rigid Frame with Attached Tops. J. Chem. Phys. 1942, 10 (7), 428-440.

(55) Pitzer, K. S. Energy Levels and Thermodynamic Functions for Molecules with Internal Rotation: II. Unsymmetrical Tops Attached to a Rigid Frame. J. Chem. Phys. 1946, 14 (4), 239-243.

(56) Bauschlicher, C. W. B.; Partridge, H. A Modification of the Gaussian-2 Approach Using Density Functional Theory. J. Chem. Phys. 1995, 103 (5), 1788-1791.

(57) Sabbe, M. K.; De Vleeschouwer, F.; Reyniers, M.-F.; Waroquier, M.; Marin, G. B. First Principles Based Group Additive Values for the Gas Phase Standard Entropy and Heat 
Capacity of Hydrocarbons and Hydrocarbon Radicals. J. Phys. Chem. A 2008, 112 (47), 12235-12251.

(58) Holmes, J. L.; Aubry, C. Group Additivity Values for Estimating the Enthalpy of Formation of Organic Compounds: An Update and Reappraisal. 1. C, H, and O. J. Phys. Chem. A 2011, 115 (38), 10576-10586.

(59) Burke, S. M.; Simmie, J. M.; Curran, H. J. Critical Evaluation of Thermochemical Properties of C1-C4 Species: Updated Group-Contributions to Estimate Thermochemical Properties. $J$. Phys. Chem. Ref. Data 2015, 44 (1), 013101.

(60) Muller, C.; Michel, V.; Scacchi, G.; Côme, G. M. Thergas - a Computer-Program for the Evaluation of Thermochemical Data of Molecules and Free-Radicals in the Gas-Phase. J Chim Phys 1995, 92 (5), 1154-1178.

(61) Blurock, E. S.; Warth, V.; Grandmougin, X.; Bounaceur, R.; Glaude, P.-A.; Battin-Leclerc, F. JTHERGAS: Thermodynamic Estimation from 2D Graphical Representations of Molecules. Energy 2012, 43 (1), 161-171.

(62) Domalski, E.; Hearing, E. Estimation of the Thermodynamic Properties of C-H-N-O-SHalogen Compounds at 298.15K. J. Phys. Chem. Ref. Data 1993, 22 (4), 805-1159.

(63) Bader, R. F. W. Atoms in Molecules: A Quantum Theory; Oxford University Press: Oxford, UK, 1990.

(64) Biegler-König, F.; Schönborn, J.; Bayles, D. AIM2000. J. Comput. Chem. 2001, 22, 545.

(65) Parra, R. D.; Streu, K. Hydrogen Bond Cooperativity in Polyols: A DFT and AIM Study. Comput. Theor. Chem. 2011, 967 (1), 12-18.

(66) Castillo, N.; Matta, C. F.; Boyd, R. J. The First Example of a Cage Critical Point in a Single Ring: A Novel Twisted $\alpha$-Helical Ring Topology. Chem. Phys. Lett. 2005, 409 (4-6), 265-269.

(67) Zheng, J.; Yu, T.; Papajak, E.; Alecu, I. M.; Mielke, S. L.; Truhlar, D. G. Practical Methods for Including Torsional Anharmonicity in Thermochemical Calculations on Complex Molecules: The Internal-Coordinate Multi-Structural Approximation. Phys. Chem. Chem. Phys. 2011, 13 (23), 10885-10907.

(68) Yu, T.; Zheng, J.; Truhlar, D. G. Statistical Thermodynamics of the Isomerization Reaction between N-Heptane and Isoheptane. Phys. Chem. Chem. Phys. 2011, 14 (2), $482-494$.

(69) Zheng, J.; Truhlar, D. G. Quantum Thermochemistry: Multistructural Method with Torsional Anharmonicity Based on a Coupled Torsional Potential. J. Chem. Theory Comput. 2013, 9 (3), 1356-1367.

(70) Kang, J. S.; Moon, Y. S.; Lee, S. H. Inhibition Properties of Three Acetylcholinesterases of the Pinewood Nematode Bursaphelenchus Xylophilus by Organophosphates and Carbamates. Pestic. Biochem. Physiol. 2012, 104 (2), 157-162.

(71) Combescot-Lang, C.; Stichele, R. H. V.; Toubate, B.; Veirron, E.; Mumcuoglu, K. Y. Ex Vivo Effectiveness of French over-the-Counter Products against Head Lice (Pediculus Humanus Capitis De Geer, 1778). Parasitol. Res. 2015, 114 (5), 1779-1792.

(72) Tsang, W. Heats of Formation of Organic Free Radicals by Kinetic Methods. In Energetics of organic free radicals; Simões, J., Greenberg, A., Liebman, Eds.; Blackie A\&P: Glasgow, 1996; pp 22-58. 


\section{Labeled Table of Contents Graphic}

Figure 1. Examples of organophosphorus chemicals. Molecules of (a) Sarin, (b) Soman, (c) Tabun , (d) VX (chemical warfare nerve agents), (e) DMMP (surrogate and fire retardant), (f) Glyphosate (herbicide), (g) Fenamiphos (insecticide and nematicide), (h) Methyl Tolclofos (fungicide)

Figure 2. Structure of $\mathrm{P}_{4} \mathrm{O}_{6}$ and $\mathrm{P}_{4} \mathrm{O}_{10}$ optimized at the B3LYP/6-311G(2d,p,p) in the CBS-QB3 composite method. Calculated bond lengths and angles are displayed in normal case, italic numbers are experimental values reported by Gurvich et al. ${ }^{9}$

Figure 3. Molecular graphs obtained from the AIM analysis. (a) most stable conformer of glyphosate, (b) "all-trans" conformation.

Figure 4. Bond dissociation energies in Sarin, calculated at the CBS-QB3 level (kcal/mol)

Figure 5. Bond dissociation energies in Tabun, calculated at the CBS-QB3 level (kcal/mol) 